\title{
TOURISM QUALITATIVE FORECASTING SCENARIO BUILDING THROUGH THE DELPHI TECHNIQUE
}

\author{
Claudete Oliveira Moreira* \\ University of Coimbra \\ https://orcid.org/0000-0002-9188-191X \\ Norberto Santos \\ University of Coimbra \\ https://orcid.org/0000-0003-1752-9990
}

\begin{abstract}
Futures analyses and scenario-building exercises have received scant attention from scientific literature on the planning and management of tourist destinations. This article emphasizes the importance of a territorial foresight strategy and scenario building in the planning and management of tourist destinations, demonstrating how it is methodologically possible to combine the Delphi technique with a scenario-building exercise. The findings suggest that the knowledge provided by stakeholders operating within the tourism system can benefit the planning and management of tourist destinations.

Keywords: Delphi technique; scenario building; tourism futures research; qualitative forecasting in tourism; strategic territorial foresight; destination management.

\section{Los análisis prospectivos del turismo: construcción de escenarios mediante la técnica Delphi}

\section{RESUMEN}

Los análisis de futuros y los ejercicios de construcción de escenarios han recibido escasa atención de la literatura científica sobre la planificación y gestión de destinos turísticos. Este artículo enfatiza la importancia de una estrategia de previsión territorial y de la creación de escenarios en la planificación y gestión de destinos turísticos, demostrando cómo es metodológicamente posible combinar la técnica Delphi con un ejercicio de creación de escenarios.
\end{abstract}

Fecha de recepción: 12 de mayo de 2019

Fecha de aceptación: 5 de marzo de 2020

* University of Coimbra. Centre of Studies on Geography and Spatial Planning. Faculty of Arts and Humanities. Largo D. Dinis, Colégio São Jerónimo, 3004-530 COIMBRA (Portugal). Email: claudete@fl.uc.pt, norgeo@ci.uc.pt 
Los hallazgos sugieren que el conocimiento de las partes interesadas puede beneficiar la planificación y la gestión de los destinos turísticos.

Palabras clave: Técnica Delphi; construcción de escenarios; investigación de futuros. en el turismo, la previsión cualitativa en el turismo; visión estratégica territorial; gestión de destinos.

\section{INTRODUCTION}

Thinking about the future without resorting to fiction requires time-consuming and complex exercises in simulation, forecasting, opinion-seeking, projection, exciting domains that in postmodern society are essential in terms of strategy, trend identification, planning and tourist destination management. In the context of tourism studies, the Tourism Area Life Cycle (TALC) model formulated by Butler $(1980 ; 2006)$ is one of those most cited and applied. It analyses the development of tourism and of tourist destinations over time by correlating the number of tourists ( $y$ axis) and time (axis $x$ ), thereby becoming established as a model with predictive potential (Berry, 2006).

In the context of tourism futures research, Delphi is one of the most widely used techniques, and scenario building is becoming more common. Benckendorff (2007) recognizes the greater potential for the use of futures methods and techniques in tourism. Wright, Cairns, and Bradfield (2013) set out the state-of-the-art in the scenario technique and make it clear that combining a Delphi technique with scenario development is common in a research context. Van Doorn (1986) suggests that scenarios should be developed and applied together with other forecasting techniques, notably the Delphi technique. Van Doorn (1982) and Calantone, Di Benedetto, and Bojanic (1987) included Delphi forecasting and scenario writing in the speculative forecasting techniques that they distinguish from three other forms of forecasting: exploratory, normative and integrative. Calantone, Di Benedetto and Bojanic (1987) review tourism forecasting literature in the 1980s and outline the relative usefulness of the different methods in specific forecasting situations. They report some applications of the Delphi technique to tourism forecasting, concluding, at the time, that scenario writing is a relatively underused tourism forecasting technique. A few years later, Witt and Witt (1995: 448) note that "empirical research on qualitative forecasting in tourism has centred on Delphi studies and scenarios". Lin and Song (2015a) came to the same conclusion (see also Lin \& Song, 2015b) when analysing the judgemental forecasting techniques used in empirical tourism studies published since the 1970s. They conclude that the Delphi technique and scenario writing are the two most popular.

In methodological terms this article combines two futures techniques that are both based on an essentially descriptive analysis: the Delphi technique with scenario creation. It exploits a method that involves experts' judgement, the Delphi technique, in its most popular application, forecasting future trends, with scenario thinking, a judgement-aided technique for plausible futures. A pairing of techniques very similar to the one we propose was carried out by Solnet, Baum, Kralj, et al. (2014) to identify the challenges of long-term 
planning (2030) for a tourism workforce at a regional level in the Asia-Pacific region, and by Kaufmann (2016) to explore the scenarios for the development of Dalmatia-Croatia, for the time frame 2014-2031. In the case of the present article, in 2010 and 2011 a panel of local, subregional and regional stakeholders used a Delphi process to develop a strategic territorial foresight exercise focused exploiting and boosting tourism in the Baixo Mondego, a subregion of the Região Centro de Portugal. Four scenarios were developed, with a 2020time horizon. The goals of this article are: to show how qualitative forecasting and scenario creation can be developed using a Delphi technique; to weigh up the virtues and limitations; and, in the stipulated year of 2020, to assess the adjustment of tourism to the subregional level. This is an unusual exercise since the techniques are generally applied and the results presented without ever assessing any divergences from reality. The Delphi technique was implemented in three rounds, defined a priori. The scenario building exercise had three stages: Stage 1 - exploration and identification, focuses on critical uncertainties; Stage 2 - selection and definition, focuses on the forces that drive change; Stage 3 - summary, scenario building. These stages corresponded to the three rounds of the Delphi technique. It should be noted that these three stages must be followed by a fourth stage, which must arise a posteriori, at a later date, Stage 4 -to monitor the scenarios created. This article lies precisely within the scope of this fourth stage: monitoring.

\section{FUTURES TECHNIQUES IN TOURISM STUDIES}

Five paradigmatic approaches or epistemological traditions were identified by Gidley (2013) in terms of futures studies, within a bifurcation between the positivist and postpositivist. Positivist approaches to "the future", refer to one, singular and probable future, inside this we have predictive-empiricaltradition (based on trend analysis, time series analysis and prediction, originated in the USA and supported by the formation of the World Future Society in the late 1960s). Post-positivist approaches contemplate "multiple futures", inside this we have the critical-postmodern tradition (based on an empirical approach to futures, referring to preferred futures, originated in Europe, particularly in France, and relates to the foundation of the World Futures Studies Federation in the early 1970s); the cultural-interpretivetradition (based on possible and alternative futures, which considered non-Western cultures and feminist futures, originated inside the World Futures Studies Federation, in the 1980s); the prospective-action approach(based onempowerment and transformation through engagement of participants in research projects, participatory futures, prospective and action research, originated in Europe in the 1990s); and the integrative-holistic futures approach (based on global justice, planetary and integral futures, newly emerging).

However, in tourism research the prevailing approximation to the future pathways has been anchored in a positivist approach where trends are analysed on the basis of quantitative models. Nevertheless, qualitative forecasting techniques have been gaining importance in the field of tourism futures research and proved to be very useful. Uysal and Crompton (1985) show that quantitative techniques are more suitable for short-term forecasting whereas qualitative judgmental approaches may be more useful for medium or long-term projections. In terms of qualitative forecasting as Benckendorff (2007: 26) 
notes "futures research generally does not seek to predict the future. Futurists are usually interested in helping decisions makers to better understand future possibilities in order to improve decisions in the present". In this regard, qualitative judgmental approaches to the future pathways adopted by tourism stakeholders can support the action of destination managers.

A number of techniques can be used in the context of qualitative forecasting in tourism. Prideaux, Laws, and Faulkner (2003) identify deficiencies in current forecasting techniques. Lin and Song (2015a) present a reasonably complete systematization of some of the judgemental forecasting techniques in tourism, organized in four groups according to their orientation, thus: asking stakeholders; asking experts; asking the public: surveys; judgement-aided methods. A categorization which nonetheless does not consider the futures wheel used by Benckendorff (2007) for researching sustainable tourism futures, for instance. The Delphi technique and scenario building have been frequently used in research, as will be discussed below, and can be used conjointly for qualitative tourism forecasting.

\subsection{The Delphi technique}

The Delphi technique, "one of the best known and sometimes more controversial methods for making forecasting", according to Smith (2013: 143), can have various designations, as Jennings observes (2010): Delphi technique, Delphi interviews, Delphi poll, executive judgement method or knowledgeable panel method. According to Cooke (1991) the Delphi technique has undergone many variations.

It is a scientific research technique that values the knowledge and opinion of a panel of experts, based on judgements and interpretations. Each member of the panel participates on an individual, anonymous, non-face-to-face basis. They take part in a prospective reflection in which the collective interest is usually highlighted, foreseeing the future(s), envisaging trends, proposing courses of action, inducing decision taking. The panel's opinions and consensus are refined in successive rounds, based on the controlled feedback each participant receives from the results of the preceding round.

The technique gets its name from the oracle of Delphi. In classical antiquity the Greeks used oracles to question the gods to foresee the future and take decisions (Delbecq, Van de Ven \& Gustafson, 1986; Charlton, 2001; Jennings, 2010; Veal, 2018). The Delphi technique uses experts as oracles (Davé, 2016).

In the field of tourism research, the Delphi technique began to attract attention towards the end of the 1970s (Robinson, 1979). The Delphi technique starts to be used more often from the mid-1980s (Edgell, Seely \& Iglarsh, 1980; Seely, Iglarsh \& Edgell, 1980; Kaynak \& Macauley, 1984; Var, 1984; Liu, 1988; Green, Hunter \& Moore, 1989; Taylor \& Judd, 1989; Yong, Keng \& Leng, 1989), and is used increasingly from then on (Green, Hunter \& Moore, 1990; Kaynak, Bloom \& Leibold, 1994; Moeller \& Shafer, 1994; Pan, Vega, Vella, Archer \& Parlett, 1995; Müller, 1998; O’Connor \& Frew, 2000; Miller, 2001; Ramos, 2001; Cunliffe, 2002; Gonçalves, 2003; Masberg, Chase \& Madlem, 2004; Kuo, Hsiao \& Yu, 2005; Ramos, 2005; Briedenhann \& Butts, 2006; Gonçalves, 2006; Kaynak \& Marandu, 2006; Kaynak \& Cavlek, 2007; Weston \& Davies, 2007; Lee \& King, 2008; 
Northcote, Lee, Chok \& Wegner, 2008; Spenceley, 2008; Briedenhann, 2009; Lee \& King, 2009; Van Ginneken, 2011; Wu, Yu \& Zeng, 2011; García-Melón, Gómez-Navarro \& Acuña-Dutra, 2012; Kardaras, Karakostas \& Mamakou, 2013; Oh, Kim \& Lee, 2013; Kaynak \& Rojas-Méndez, 2014; Szpilko, 2014; Von Bergner \& Lohmann, 2014; Fernandes, 2015; Gani, 2015; Konu, 2015; Locke, 2015; Ballantyne, Hughes \& Bond, 2016; Fefer, Stone, Daigle \& Silka, 2016; Marques \& Santos, 2016; Silveira, 2016; Witt, Moutinho, Huarng \& Yu, 2018). The Delphi technique has been used for different purposes. As Guttentag and Smith remark (2016: 231) "although still not common in tourism, its popularity has grown and the technique has been used to examine diverse tourism topics."

The second decade of the present century has seen new combinations emerge in the use of the Delphi technique in research on tourism, thus: a combination of Analytic Network Process (ANP) with Delphi technique (García-Melón, Gómez-Navarro \& Acuña-Dutra, 2012; Zhang, 2017), Analytic Hierarchy Process and Delphi technique (AHP-Delphi) (Chen, Ng, Huang \& Fang, 2017) and applications of a Fuzzy Delphi Method (Kardaras, Karakostas \& Mamakou, 2013).

The virtues and weaknesses of applying the Delphi technique are often and extensively explored in the literature, albeit with a greater or lesser degree of development depending on the reference in question (Taylor \& Judd, 1989; Green, Hunter \& Moore, 1990; Godet, 1993; Moeller \& Shafer, 1994; Frechtling, 1996; Müller, 1998; Frechtling, 2001; Perez, 2001; Gunn \& Var, 2002; Landeta, Matey, Ruíz \& Villarreal, 2002; Gonçalves, 2003; Garrod \& Fyall, 2005; Ramos, 2005; Gonçalves, 2006; Landeta, 2006; Cooper, 2008; Donohoe \& Needham, 2009; Jennings, 2010; Botterill \& Platenkamp, 2012; Moreira, 2012; Marques, 2013; Moreira, 2013; Konu, 2015; Fefer, Stone, Daigle \& Silka, 2016; Guttentag \& Smith, 2016; Silveira, 2016).

The advantages of the Delphi technique include the fact that it is appropriate for dealing with a range of research questions, particularly when there is a lack of systematic knowledge about the topic or problem. The Delphi technique makes it possible to structure non-face-to-face group communication and produce a platform of consensus. This is because its use eliminates the effect of domination and leadership that is inherent in interpersonal relationships in group dynamics in which a topic and/or issue is considered and discussed in order to garner opinions. In a face-to-face group discussion, there is a tendency to express the points of view that are consensual (Frechtling, 1996; Frechtling, 2001; Perez, 2001). With the Delphi technique, all interaction is anonymous so as not to influence the expression of opinion. The anonymity of the panellists is one of the virtues of this technique (Gupta \& Clarke, 1996; Perez, 2001; Witt, Moutinho, Huarng \& Yu, 2018). It does not require a large number of panellists, as the quality and expertise of the participants is what is relevant. Since the opinions expressed do not have to be socially accepted, they can be freely shared. What is more, it incorporates the valuable formal and informal knowledge and experience of the panel members. It also enables the presentation of a range of considered and well-grounded opinions, which encourages the identification of instances of both consensus and difference, thereby leading to a more polished analysis. As the technique does not require face-to-face interaction, participants can take part from afar, and neither time nor money are wasted in travel to attend sessions. 
Panel participants must be very carefully chosen to fit the study's objectives. It is also essential that coordinators and participants have the necessary free time available to dedicate, as the procedure takes place over several rounds. Successive re-evaluations take place in which participants consider their assessment in response to feedback, subject to the influence of the group opinion. There is the risk that participants may get fed up and drop out due to the need to engage in successive rounds, always responding to the same issues. It is therefore necessary that participants be highly motivated and committed. A lack of response in later rounds may prove a problem. Along the same line, a failure to achieve consensus may lead to the elimination of some opinions, thereby weakening the analysis. Moreover, the results cannot be considered absolute, but are relative to a certain time period and panel of experts. Finally, it must be born in mind that, in most cases, the panellists lack sufficient formal knowledge that would enable them to make forecasts and prospective analyses, due to the limitations of their empirical knowledge. For coordinators, there are several procedures requiring caution and time as laid out in Figure 1 (points 1.1., 2.1., 3.1. and 4.1.)

Figure 1 shows the steps involved in the Delphi process. Gupta and Clarke (1996) emphasize that the goal of the technique is neither to achieve a single response nor to reach a consensus, but rather to obtain high quality responses and opinions to support decision making. Garrod and Fyall (2005) point out exactly that the recent application of the Delphi technique does not exclusively seek a convergence of opinion, since a divergence of the opinion of the panellists can also be considered valid. Landeta (2006), too, stresses that one of the targets that featured when the Delphi technique was first used, the achievement of consensus, is no longer mandatory in the latest applications of this social research technique. In fact, today, we often try to use a group of experts to get a reliable, credible opinion. Guttentag and Smith (2016:231) note that "originally developed for forecasting, Delphi is now also used for decision making and issue analysis. It was originally intended to result in group consensus, although it can also provide insights into contrasting viewpoints."

It is often held that the choice of the participants in the panel determines the final results, since a balanced composition of the panel and maintaining such balance over the successive rounds is a key factor in the application of the Delphi technique (Moeller \& Shafer, 1983; Taylor \& Judd, 1989; Godet, 1993; Frechtling, 1996; Charlton, 2001; Frechtling, 2001; Perez, 2001; Linstone \& Turoff, 2002; Gonçalves, 2003; Garrod \& Fyall, 2005; Cooper, 2008; Jennings, 2010; Moreira, 2012; Smith, 2013).

In the case of tourism research, Frechtling $(1996 ; 2001)$ notes that the panel should represent a broad spectrum of interests and experiences, ranging from skilled managers, academics, consultants, government officials, business analysts, representatives of accommodation, catering, transport and/or attractions services, besides other more specific actors and interest groups linked to the destination. In this context, Wall (2009) emphasizes the importance of involving stakeholders in the decision-making processes related to heritage and tourism. Although the author recognizes that the goals differ, especially in the short term, when there are sometimes tensions and disagreements between them, in the long term there is generally a greater agreement. Planning sustainable tourism requires an appreciation of the different viewpoints, which is very relevant when it comes to culti- 
vating dialogue between the various participants (academics, policymakers, development promoters, conservationists and the resident population, who are part of the local community). In tourism, the knowledge held by the stakeholders is important, as it is shared quite widely, which makes it quite hard to manage it (Silva, Jafari \& Scott, 2010), so the Delphi technique is very useful.

\section{Figure 1 \\ CONCEPTUALIZATION OF THE DELPHI TECHNIQUE}

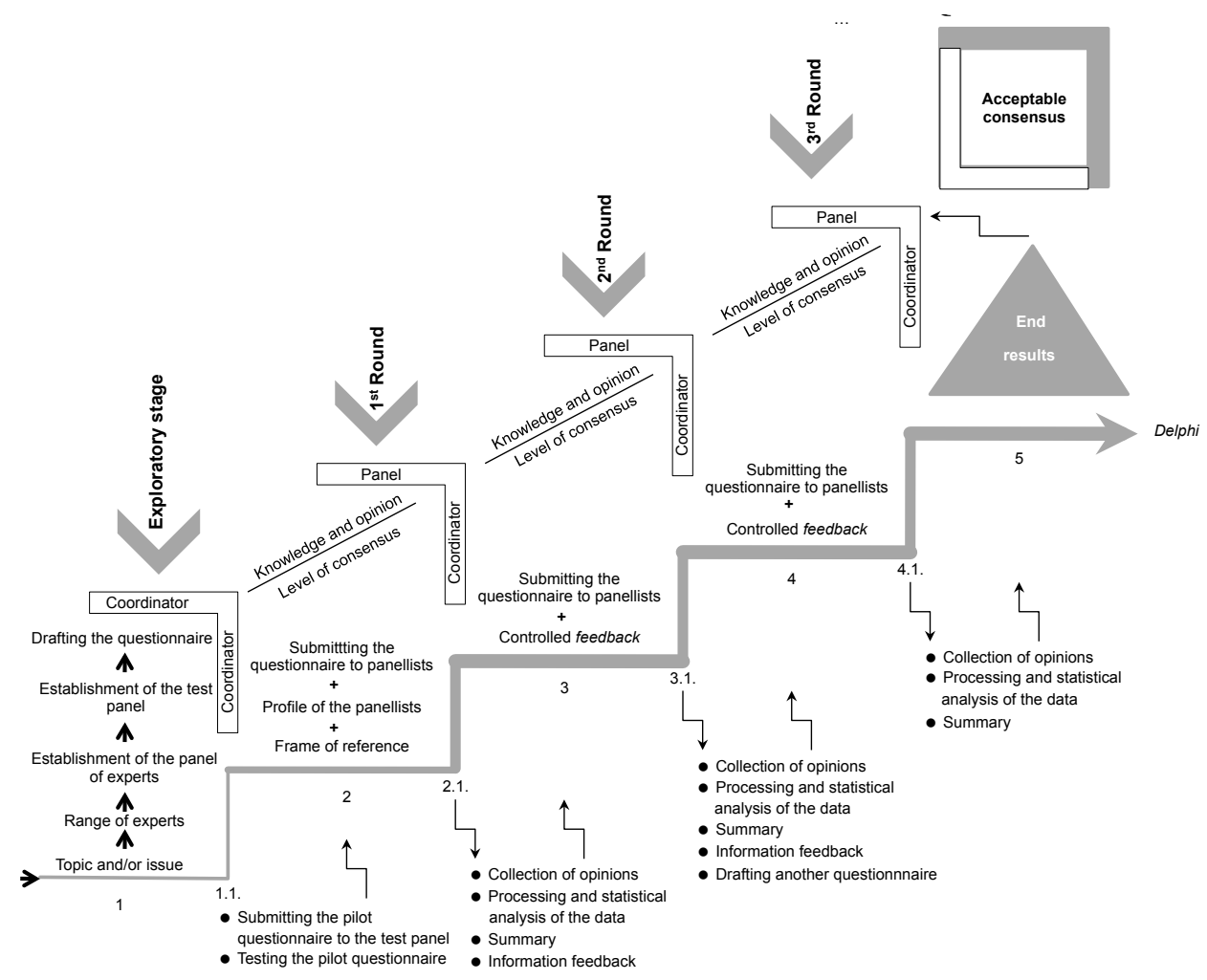

Source: Moreira, C. O. (2013: 363).

The Delphi technique is time-consuming; each panellist will need time to complete each questionnaire and time to respond to successive rounds. Moreover, as the participants are face with the same matters and questions in successive rounds there is the risk of fatigue and saturation. One critical aspect that is often reported is panel members' dissent (Frechtling, 1996; Frechtling, 2001; Garrod \& Fyall, 2005; Landeta, 2006). It is understood that the ways used to reduce the rate of dissidence should include these assumptions: the coordinator will meet each of the panellists beforehand; the final results are of interest to the panellists and encourage their input during the rounds. 
Because successive rounds are involved, a scenario-building exercise can be included when applying the Delphi technique.

\subsection{Creating the scenarios}

The scenarios are descriptions, different plausible narratives of future situations. A scenario is defined as "a set of hypothetical events set in the future constructed to clarify a possible chain of causal events as well as their decision points" (Kahn \& Wiener, 1967: 6). The creation of scenarios in the planning and strategic management of tourist destinations has been of increasing interest and proved to be very useful in tourism. This is largely because of the inherent complexity of the tourism system, the indeterminacy, turbulence, instability and uncertainty to which it is subject by virtue of being an open system, which makes it extremely sensitive to changes in the external elements that provide its context.

Forecasting changes in the elements surrounding the tourism system and thinking about the impacts on its components and tourist destinations by creating scenarios - possible, probable, inevitable, desirable - based on probable developments is an exciting field of research, since it helps to guide decision taking and to create competitive advantages in tourist destinations. Gössling and Scott (2012: 774) note that "scenario planning is inextricably linked to forecasting, which is widely used and accepted for business and government decision-making in tourism".

Forecasting helps strategic reflection (Gouirand, 1996), and territorial foresight is part of the strategic management of a territory. Foresight is an instrument of strategy, it becomes an instrument of knowledge and conceptualization, and prospective reflection is inseparable from action. This perspective is found in Godet (1996) for whom foresight and strategy are indivisible, hence the expression strategic foresight is often used. Foresight encourages the active involvement of all those who have acquired knowledge and experience that are relevant so that they can be shared to shape and enlighten the possible futures and mark the best route to get to the most wished-for future. This lets us know not only the possible futures but also the perspectives of everyone who is involved in the exercise and makes it possible to link these perspectives and visions in the medium and long term. A foresight exercise assumes a participatory process which considers residents, actors, agents and interest groups, policymakers and others responsible for local, subregional and regional administration, entrepreneurs and researchers. It is important to widen the network of stakeholders. In addition to the stakeholders, their projects, strategies, relationships, alliances and dissent should be considered. In this context, it should be noted that foresight can help to generate consensus. Prospective reflection allows us to collectively understand the challenges and opportunities, something that is relevant to the positioning of stakeholders. One of the techniques of forecasting is the construction of scenarios, as mentioned above.

Scenario building was not used in the field of tourism studies until around the nineteeneighties (Van Doorn, 1986). More complex and innovative scenario-building techniques have emerged more recently in the area of tourism research, as noted by Gössling and Scott (2012). Currently the most use of scenario planning in tourism has been made by Ian Yeoman and others (Yeoman \& Lederer, 2005; Lennon \& Yeoman, 2007; Yeoman, 
2008; Page, Yeoman, Connell \& Greenwood, 2010), by Daconto and Sherpa (2010), by McLennan, Pham, Ruhanen, Ritchie and Moyle (2012), by Pizzituttia, Walshc, Rindfussd, et al. (2017), and by Nyaupane and Buzinde (2017). Mai and Smith (2018) explore system dynamic modelling as an alternative to forecasting models for the scenario-based planning of tourism destinations. Postma (2015: 48) further states that "in tourism futures studies and scenario planning are still in its (sic) infancy". The creation of the European Tourism Futures Institute (ETFI) in 2009 (https://www.etfi.nl/en) clearly shows the importance of such studies in the field of tourism. Postma (2015: 46) says that "the European Tourism Futures Institute wants to play a significant role in the development of futures studies and scenario planning in tourism, to the professionalization of the approach and to the education of contemporary and future professionals."

There are various ways of constructing scenarios (Pillkahn, 2008; Amer, Daim \& Jetter, 2013). The construction takes four quadrants, a $2 \times 2$ matrix approach, based on the definition of two contrasting axes we get four different scenarios. This was the technique chosen in this research to drafting the scenario framework.

It was intended to develop a prospective, participatory, collectively shared reflection that is structured on the basis of a scenario building exercise, looking at futures and an inclusive view of the territory and tourism, and their directionality for a subregion of the Centro of Portugal, the Baixo (Lower) Mondego.

\section{STUDY AREA AND METHODOLOGY}

\subsection{The study area}

On the coast of central Portugal is an area known for centuries as Baixo Mondego (Lower Mondego). This is the final stretch of the largest river that rises in Portugal, the River Mondego. the Baixo Mondego is dominated by an extensive alluvial plain that is one of the most fertile areas of Portugal. The Baixo Mondego is made up of eight municipalities comprising an area of $2,062.8 \mathrm{~km}^{2}$ (Fig. 2).

The Baixo Mondego is a territory that has an exceptional natural and cultural heritage, tangible and intangible, and several places have historical relevance in terms of domestic tourism. Coimbra is the main city; it is a regional centre for services such as health and education and the focal point of tourism supply and demand. Coimbra has one of the oldest universities in the world, founded in 1290. Both tourism supply and demand have been on the rise between 2010 and 2020, a trend which intensified when The University of Coimbra - Alta and Sofia was listed as a UNESCO World Heritage Site (WHS) in June 2013. Both the number of hotels and beds have grown notably (Fig. 3). The greatest supply is found in Coimbra, while the two important seaside resorts, Figueira da Foz and Mira, also offer significant quantity of accommodation.

As supply has grown, so has demand, as indicated by the number of guests and overnight stays (Fig. 4). Simultaneously, international tourism has also risen to the point that foreign tourists now account for more than half of the visitors, mostly in Coimbra (Fig. 5). However, the difficulty of spreading the touristic demand across the region is worthy of note. 
Figure 2

GEOGRAPHICAL POSITION OF BAIXO MONDEGO (LOWER MONDEGO SUBREGION), PORTUGAL

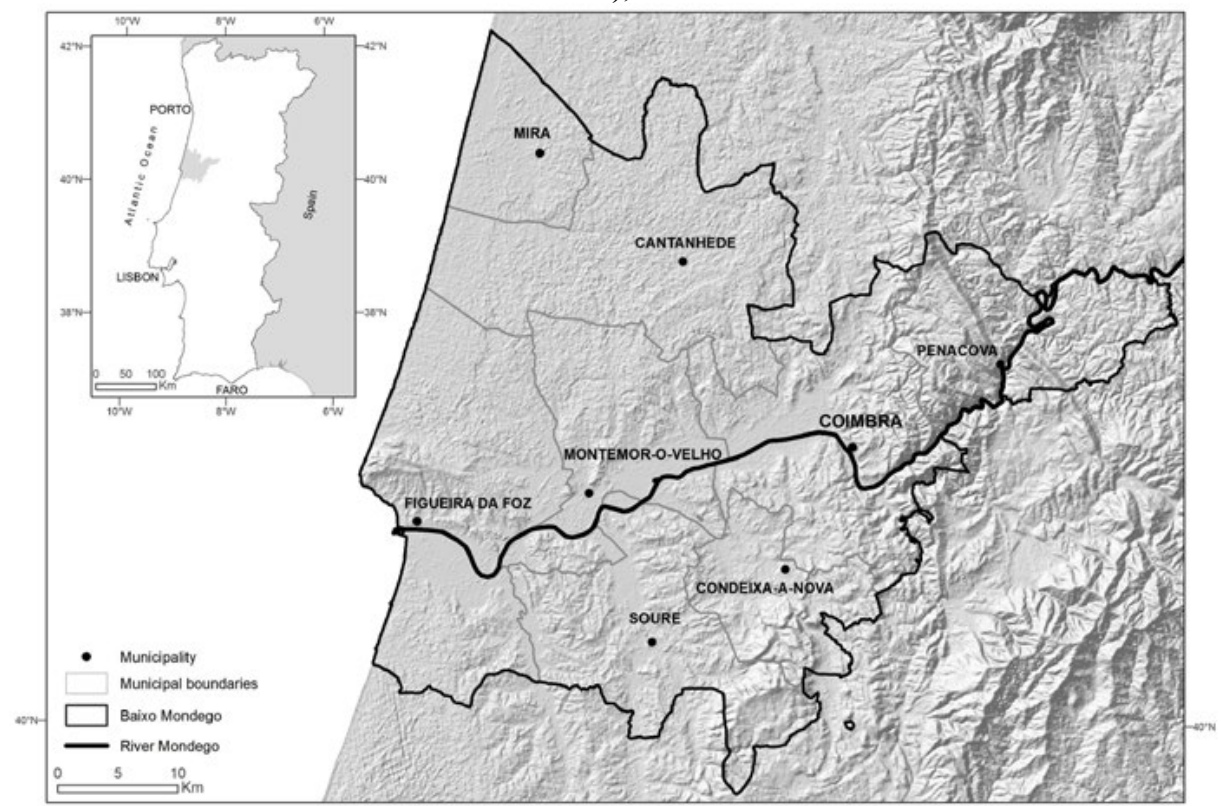

Source: Map by Claudete Oliveira Moreira and Norberto Santos.

Figure 3

CHANGE IN THE NUMBER OF HOTEL ESTABLISHMENTS AND ACCOMMODATION CAPACITY IN THE BAIXO MONDEGO, 2010 - 2018

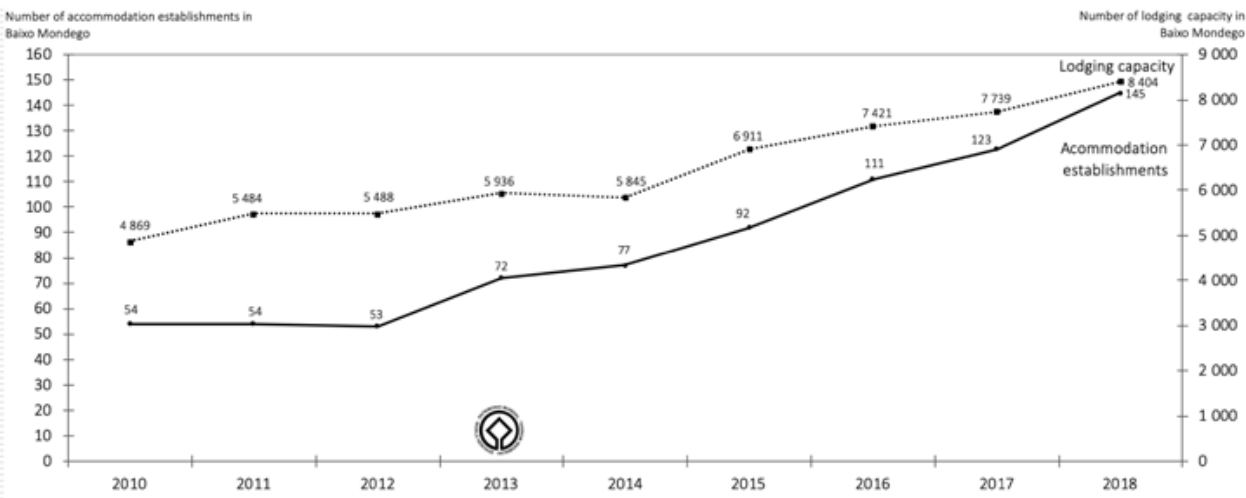

(3) Date of the recognition of the University of Coimbra - Alta and Sofia as a UNESCO World Heritage Site.

Source: data from Instituto Nacional de Estatística, Lisbon, 2020. 
Figure 4

CHANGE IN THE NUMBER OF GUESTS AND OVERNIGHT STAYS IN THE BAIXO MONDEGO, 2010 - 2018

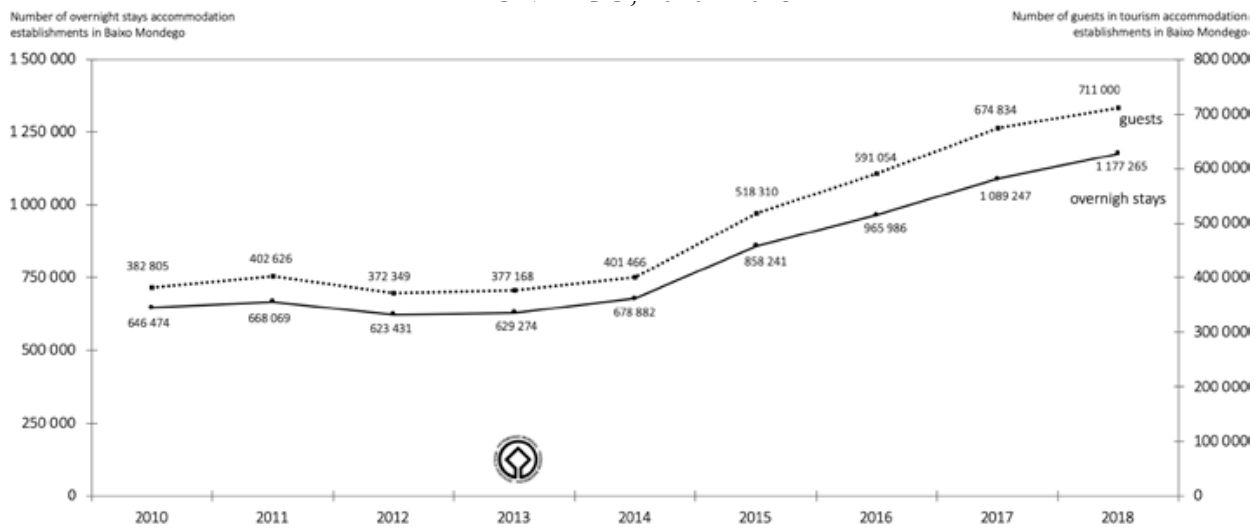

(5) Date of the recognition of the University of Coimbra - Alta and Sofia as a UNESCO World Heritage Site. Source: data from Instituto Nacional de Estatística, Lisbon, 2020.

\section{Figure 5}

\section{PERCENTAGE OF NATIONAL AND INTERNATIONAL GUESTS IN THE BAIXO MONDEGO, 2010 - 2018}

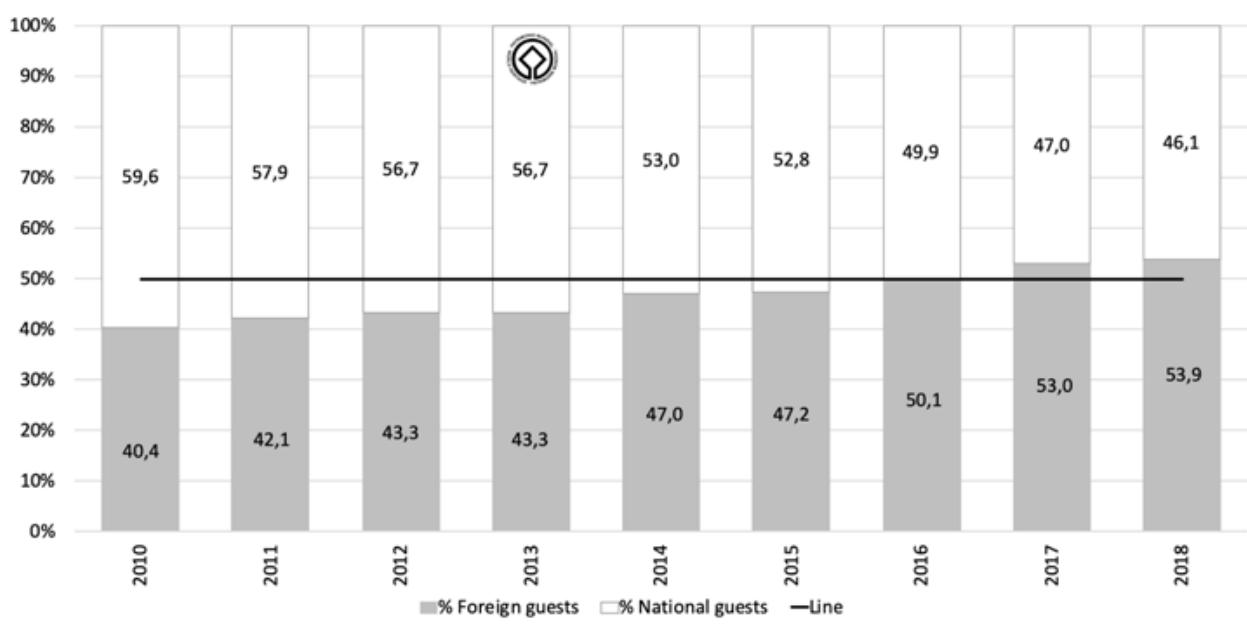

(3) Date of the recognition of the University of Coimbra - Alta and Sofia as a UNESCO World Heritage Site. Source: data from Instituto Nacional de Estatística, Lisbon, 2020.

Since it lies between Portugal's main cities of Lisbon and Porto, tourists tend to pass through places in this region and the average stay is less than two nights. This area has 
some constraints: it does not have a clear strategy for exploiting the territory and its heritage, a coherent scheme for tourism promotion, or a forward-thinking vision to guide action. Added to all this is a multiplicity of actors who lack a strong tradition of communication but who engage individually in initiatives and joint efforts to affirm the subregion on other scales, both national and supranational.

This is a territory in which the competitiveness and strategic management of tourism could greatly benefit from the convergence of opinions on future action and decision making, showing the application of the Delphi technique in tourism research combined with creation of scenarios highly appropriate to the Baixo Mondego area. A Delphi panel was set up to discuss, not in person, the topic Tourism, heritage and local development in the Baixo Mondego. Strategic Management of the destination(s).

\subsection{Methodology}

\subsubsection{Delphi technique: panel structure}

Given the complexity and scope of the theme and the problem, and the size of the territory, it was felt that it was essential to compose a heterogeneous panel, whose members had different levels of experience, but who were linked by a knowledge of the theme and/ or the territory to be able to arrive at a judgement that was valid and credible, stakeholders linked directly and indirectly to tourism.

The Delphi technique does not use any formal method of sampling, causal or noncausal, so for the present work the panel members were organized by listing a target panel $(P)$, from which the responding panel $(p)$ was established. The target panel considered in this research is composed of stakeholders who understand and/or are directly or indirectly actively engaged in tourism at local, subregional and regional level, and who operate on a daily basis in the territory of Baixo Mondego. Recognizing that in the panel the stakeholders have different organizational affiliations, interests and responsibilities, we chose to form four groupings (A, B, C and D) and fifteen groups (Fig. 6). The methodology used was not completely identical to previous investigations, although the procedures for intra group analysis were present in Frechtling (1996; 2001). In this case, in order to better understand the subject under study, it was assumed that this division would better enable researchers to compare and more easily identify commonalities, while more easily spotting any opinion differences amongst specialists (politicians, academics, private and public managers).

Seventy-three potential participants were contacted through face-to-face meetings, 51 tourism stakeholders took part in the first round, 48 in the second round, and 48 in the 3rd round (Fig. 6). In this application of the Delphi technique it was assumed that those members who failed to respond to one of the interactions wouldn't be reintegrated into the panel in the subsequent rounds, thereby fulfilling what Garrod and Fyall (2005) set out as good practice. Once the Delphi technique was under way, the drop-out rate was residual (the drop-out rate in the first round was just $5.9 \%(n=3)$ and that between the second and thirds round was $0 \%(n=0))$. 


\section{Figure 6 \\ STRUCTURE OF THE PANEL AND EXPLANATION OF THE APPLICATION OF THE DELPHI TECHNIQUE}

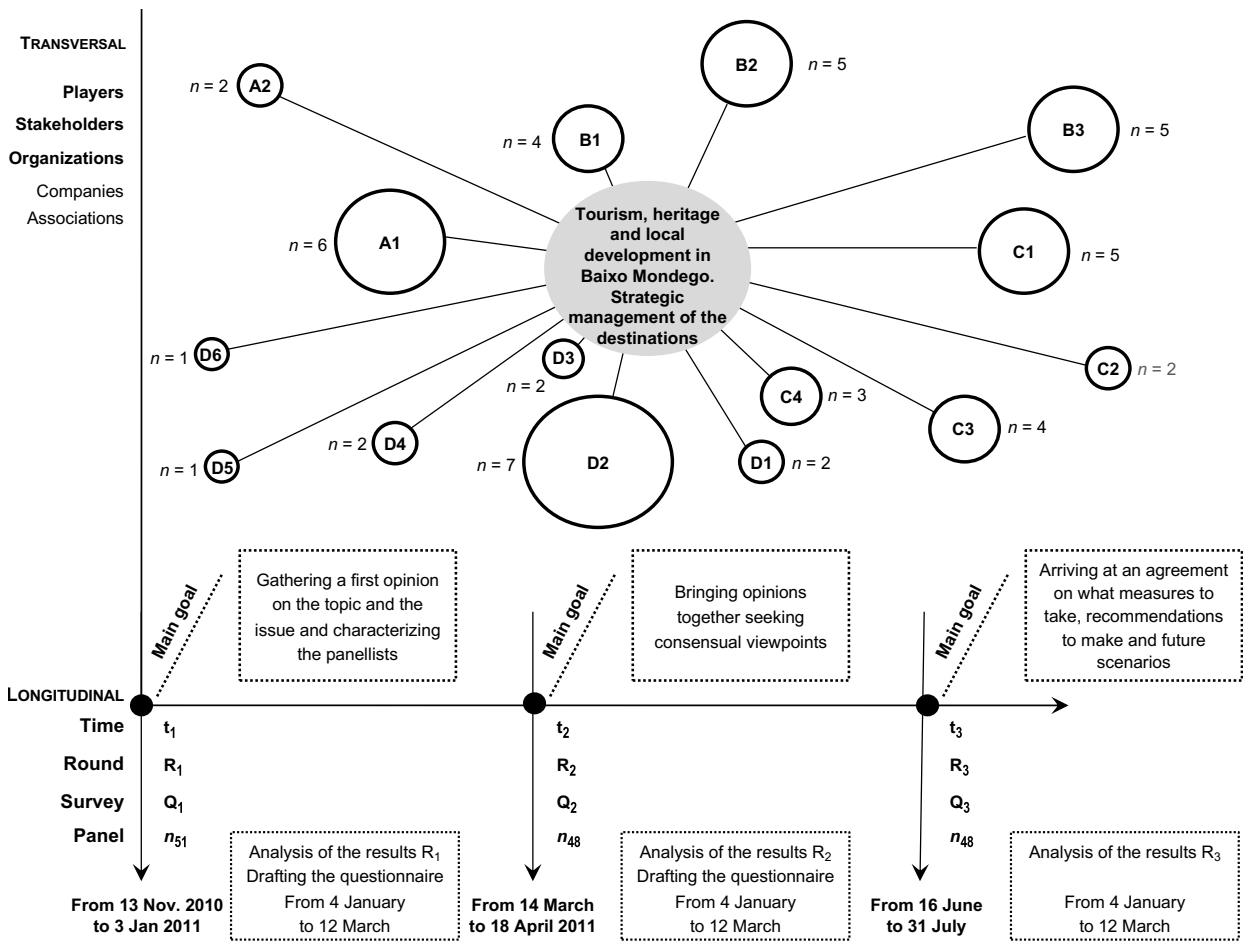

Key

A Academics

A1 University lecturers and researchers

A2 Polytechnic lecturers and researchers

B Local, subregional and regional public players

B1 Tourism-oriented public administration

B2 Local public administration, local governments

B3 Subregional and regional public administration

C Individual and/or private tourism promotion players

C1 Tourism promotion entrepreneurs and players

C2 Tourism interpreter-guides

C3 Local, subregional and regional groups linked to tourism

C4 Gastronomic brotherhoods

D Managers and executive officers of heritage assets, cultural institutions, tourist attractions, accommodation and catering units, and travel agencies

D1 Heads of hotel and tourism education and training institutions

D2 Managers and directors of tourist attractions

D3 Directors of cultural venues and events

D4 Directors and managers of accommodation units

D5 Managers of catering units and events venues

D6 Travel Agency Managers

Source: Moreira, C. O. (2013: 383).

Cuadernos de Turismo, 46, (2020), 423-457 


\subsubsection{Application of the Delphi technique: data collection}

A Delphi panel was set up to test the pilot questionnaire. It was composed of three members whose personal and professional background the coincided with the profile of the members of the actual panel but who did not make up the definitive panel: a higher education lecturer and researcher in the field of tourism; the director of a hotel with extensive experience in hotel management and tourism consultancy; and a regional public authority employee with wide experience in planning and land-use development. The test that took place from 16 to 30 October 2010 was used to validate the opinion-gathering tool, which helped to reformulate some questions and adjust the questionnaire.

It was established at the outset that the implementation of the technique would involve three rounds and that the panel participants should be allowed a period of three weeks to respond to the questionnaire. Even so, all the rounds had to be extended. Each round lasted about 45 days, on average. The application of the Delphi technique as such began on 13 November 2010 and ended on 31 July 2011, lasting for eight months and eighteen days (Fig. 6).

The instrument used to gather opinions was the self-administered questionnaire entitled: Tourism, heritage and local development in the Baixo Mondego. Strategic Management of the destination $(s)$, available on the Internet. The LimeSurvey open source survey application was used for this (http://depgeotur.uc.pt/TTD/QuestionarioDelphi/Apendices_V_8_V_9_V_10/), and the link for the individual questionnaire was sent to each of the participants by email, so the interaction was based on a virtual platform.

The questionnaire was organized in four sections: 1. Evaluation of tourism resources and products; 2 . Strategies for valuing heritage and promoting tourism; 3. Forms of cooperation and collaboration, partnerships and networks; 4. Strategies for the management, marketing and promotion of the tourist destination; 5. Additional comments and 6. Characterization of the participant in the panel (first round questionnaire only).

In section 4 of the questionnaire an exercise was developed to create scenarios and strategic territorial foresight. Thus, taking advantage of the panel created for the application of the Delphi technique and the questionnaires that supported the interaction process for three rounds, a scenario-building exercise was developed, with the stakeholders involved with tourism setting four possible future scenarios: $F_{1} C_{A}, F_{2} C_{B}, F_{3} C_{C}$ and $F_{4} C_{D}$ (Fig. 7).

The strategic territorial foresight exercise, that is, building scenarios with a view to defining possible futures (futuribles) for tourism in the Baixo Mondego, took place in three stages, over the three rounds established for applying the Delphi technique. The scenariobuilding exercise was based on a strategic focus and a predefined time horizon (Table 1).

The first is a stage of exploration and identification, focusing on critical uncertainties; the second stage, of selection and definition, focuses on the driving forces of change; the third and last stage, which we have chosen to designate as one of synthesis, is geared to focus on the construction of scenarios. The subsequent fourth stage consists of monitoring the scenarios created and includes the writing of this article. 


\section{Figure 7 \\ FRAMEWORK OF STRATEGIC FUTURES ANALYSIS APPLIED TO TOURISM}

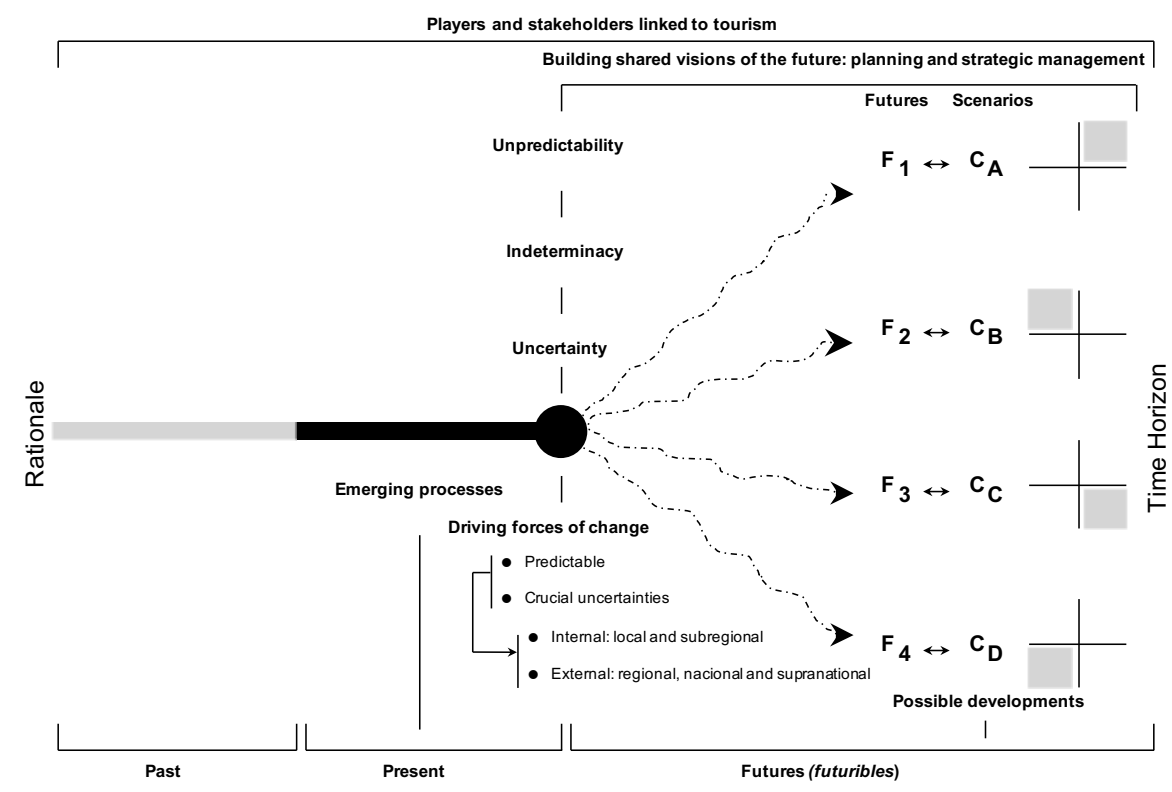

Source: Moreira, C. O. (2013: 660).

Table 1

STRATEGIC FOCUS AND TIME HORIZON SPECIFIED FOR A SCENARIOBUILDING EXERCISE

\section{Construction of scenarios}

Strategic territorial foresight for developing and promoting tourism in the Baixo Mondego

\section{Strategic focus}

Baixo Mondego

Territory's resources

Local development

Comparative advantages

Competitive advantages

Innovative changes

Tourist appeal

Integrated and competitive tourist destination

Future positioning

Time horizon 2020

Source: Based on questionnaire entitled: Tourism, heritage and local development in the Baixo Mondego. Strategic Management of the destination(s). 


\subsubsection{Stage 1: Exploration and identification - critical uncertainties}

It took place in the first round of the application of the Delphi technique. The objectives were: $(i)$ to make the participants aware of the strategic focus and time horizon (Table 1), and (ii) to get them to identify the most important and uncertain drivers of change. These driving forces are referred to as critical uncertainties and in the next stage they provide the basis of the scenarios.

Each participant was asked to give their individual opinion as to what seemed to be (1) the predictable driving forces of change, that is, that they should surmise, indicating in advance what is certain to happen.

Basically, what they were asked for were the predictable changes, which are the predetermined elements. Those forces of change for which there is a relative certainty that they will happen within the scope of the strategic focus and the defined time horizon. In this context, predictable changes, inside the territory under study (local and subregional), and outside the territory under study (regional, national and supranational). In addition, the panellists were asked to indicate (2) the driving forces of change that are crucial uncertainties, that is, those that are least predictable. Once again, inside and outside the territory under study.

Table 2

THE MOST IMPORTANT DRIVING FORCES FOR CHANGE TO ENHANCE AND PROMOTE TOURISM IN THE BAIXO MONDEGO TERRITORY, FOR THE DEFINED STRATEGIC FOCUS AND TIME HORIZON

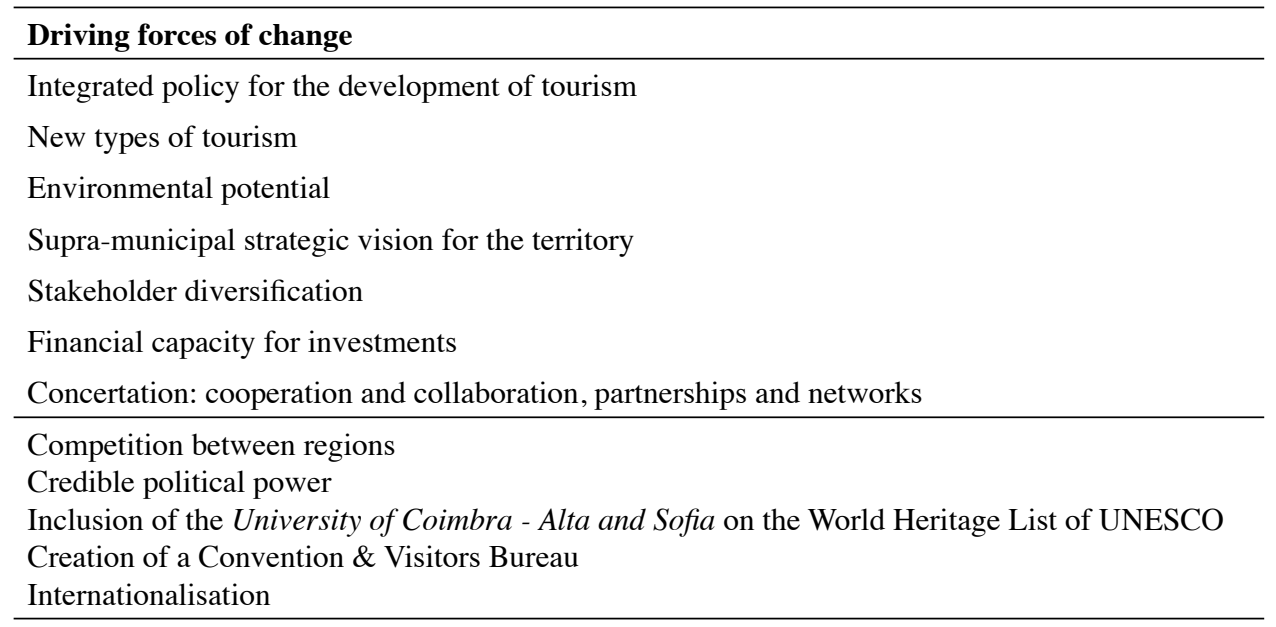

Source: Based on the opinion of the participants in the Delphi panel and questionnaire entitled: Tourism, heritage and local development in the Baixo Mondego. Strategic Management of the destination(s).

The (1) predictable driving forces of change and (2) the driving forces of change that are crucial uncertainties can be diverse in scope: social, economic, political, 
demographic, environmental, among others. The driving forces were asked for in the form of open-ended questions aimed at maximizing spontaneous opinions, assessing the analytical aptitude of the panel, and gaining creative insights. The driving forces obtained were analysed, combined, grouped and summarized by the coordinator of not in-person communication group (Table 2).

\subsubsection{Stage 2: Selection and definition - driving forces of change}

It took place in the second round of the application of the Delphi technique. The objectives were: to present the panellists with the twelve most important driving forces that resulted from the first round (Table 2); to choose the two driving forces which, despite being critical uncertainties, will yield credible future scenarios, that is, the most consensual driving forces (Fig. 8) that will be part of the scenario creation matrix, with one perpendicular to the other, shown in diagram form in an $\mathrm{x}$, y plane (Fig. 9), and to identify for each of the two selected driving forces of change, the developments in the opposite direction, that is, the positive impacts (+) and negative impacts (-) in the future, of the forces of change.

\section{Figure 8}

\section{CONSENSUS LEVEL ACHIEVED BY EACH OF THE DRIVING FORCES OF CHANGE REGARDED AS THE MOST IMPORTANT TO ENHANCE AND PROMOTE TOURISM IN THE BAIXO MONDEGO TERRITORY}

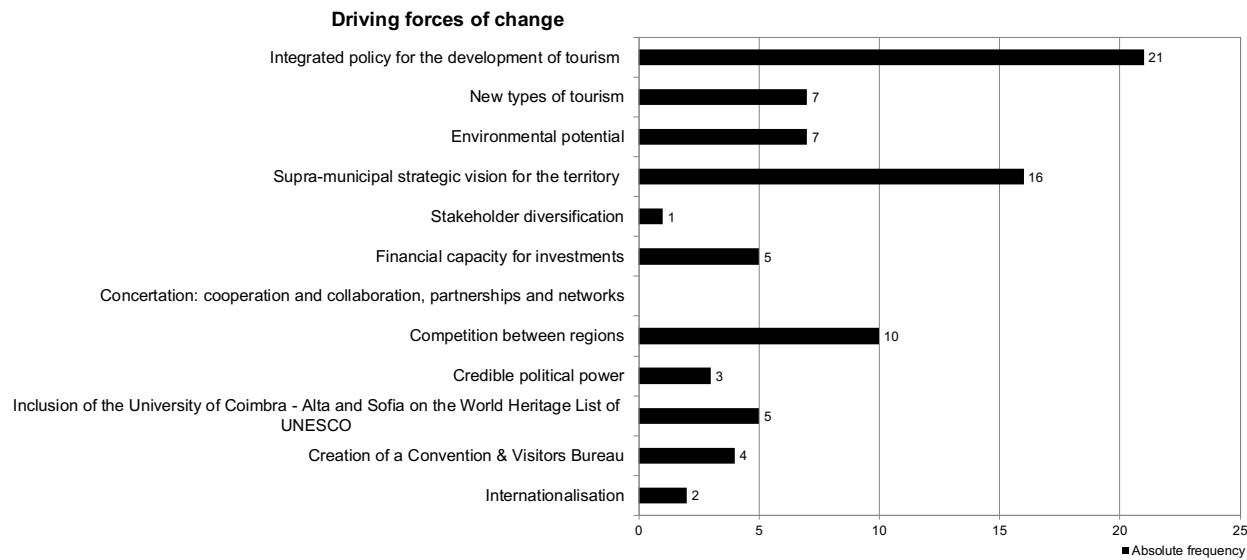

Source: Based on the opinion of the participants in the Delphi panel and questionnaire entitled: Tourism, heritage and local development in the Baixo Mondego. Strategic Management of the destination(s).

The contrasting axes, positive (+) and negative (-) impacts required for each driving force (Fig. 9) show the main causal factors in each axis of the scenario matrix. It was the task of the panel coordinator to specify the content of the contrasting axes, based on the individual contribution of each participant. This specification, although subjective, 
was not random; rather, it sought to observe some principles: (i) to scrupulously respect individual contributions, as far as possible; ( $i i)$ to consider separately what would be a positive development and a negative development; (iii) to consider the suitability of the development that would give content to the axis contrasting the driving force of change; (iv) to choose short, simple and clear words and/or expressions; (v) to gauge whether the combination and the cross-referencing of the contents of the contrasting axes, two by two, resulted in different and plausible narratives.

In view of the foregoing, and looking at Figure 9, we can easily conclude that of the four scenarios presented the most optimistic one is scenario $A\left(C_{A}\right)$, in that it combines and cross-references two positive contrasting axes. The $\mathrm{D}\left(\mathrm{C}_{\mathrm{D}}\right)$ scenario, which occupies a position diametrically opposite to that of scenario $\mathrm{A}$, is the most pessimistic scenario in that it combines and cross-references two negative contrasting axes. Scenarios B and $\mathrm{C}$ $\left(\mathrm{C}_{\mathrm{B}}\right.$ and $\left.\mathrm{C}_{\mathrm{C}}\right)$ are intermediate scenarios, i.e. mixed.

\subsubsection{Stage 3: In brief - scenario building}

It took place in the third round of the application of the Delphi technique. In a scenariobuilding matrix the four quadrants must produce distinct narratives, because only then will the scenarios be differentiated.

The goals of this stage are: to identify the causes that underlie each of the contrasting axes; to assign specifications to each of the four future scenarios, based on combining the contrasting axes and their content, a specification that would not only express the content but also identify this scenario (Fig. 9); to identify the future implications relating to each of the four scenarios; and to identify the strategic actions that should take place in the future, within each of the four scenarios (Fig. 10, Fig. 11, Fig. 12 and Fig. 13). Thus, the scenarios inspire, suggesting action, and can help to inform the decisionmaking processes.

The choice of the coordinator of the application of the Delphi technique was consider all the implications as well as all the future strategic actions proposed by the participants in the panel for each scenario, seeing this inclusive option as a way both to enrich and to give content and consistency to the process. A narrative that details the possible futures (futuribles) $\left(\mathrm{F}_{1}, \mathrm{~F}_{2}, \mathrm{~F}_{3}\right.$ and, $\left.\mathrm{F}_{4}\right)$ is matched with each of the four scenarios. The implications and the actions make it possible to create the narrative of each scenario, thereby giving the scenarios content and consistency. Building scenarios enables a more informed action. Scenario building is particularly useful for managing situations marked by uncertainty and is therefore very well suited to the planning and management of tourism. 


\section{Figure 9 \\ SCENARIO-BUILDING MATRIX SHOWING THE SCENARIOS YIELDED BY THE THIRD ROUND}

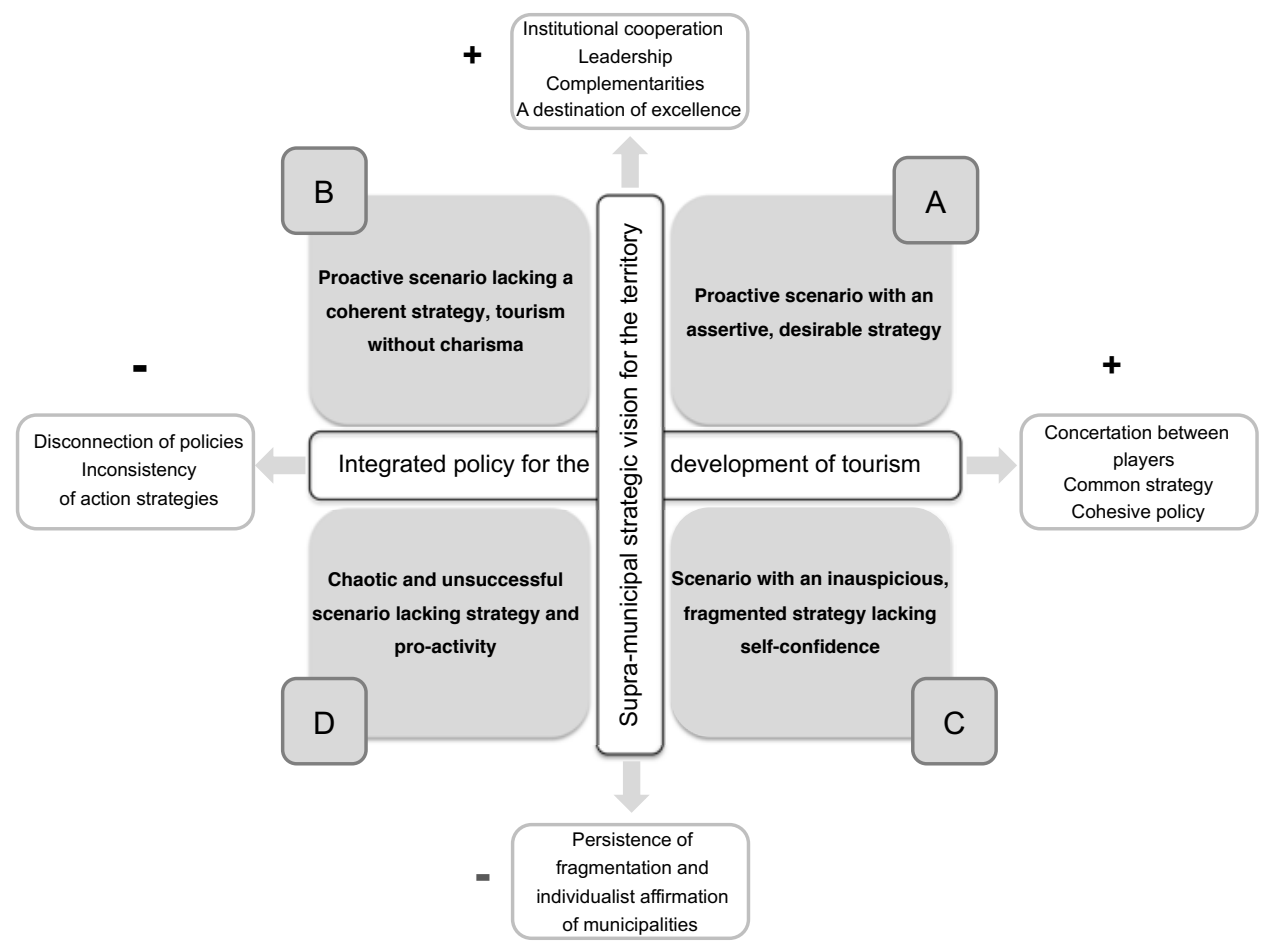

Source: Based on the opinion of the participants in the Delphi panel and questionnaire entitled: Tourism, heritage and local development in the Baixo Mondego. Strategic Management of the destination(s).

$\mathrm{F}_{1} \mathrm{C}_{\mathrm{A}^{-}}$Proactive scenario with an assertive, desirable strategy

By combining two positive lines of analysis: institutional cooperation, leadership, complementarities and a destination of excellence, as well as the coordination of actors, a common strategy and a cohesive policy comes out as the best of all the scenarios.

$\mathrm{F}_{2} \mathrm{C}_{\mathrm{B}}$ - Proactive scenario lacking a coherent strategy, tourism without charisma

This scenario results, on the one hand, from a certain institutional cooperation, leadership, complementarities and a destination of excellence, but also from a certain disarticulation of policies and an incoherence of strategies of action. 
$\mathrm{F}_{3} \mathrm{C}_{\mathrm{C}}$-Scenario with an inauspicious, fragmented strategy lacking self-confidence

This scenario results, on the one hand from the combination, even conflicting, between a lack of concerted action by the actors, a difficulty in defining a common strategy and a cohesive policy, the existing policy being inoperative, and a certain persistence of fragmentation and isolated affirmation of municipalities.

$\mathrm{F}_{4} \mathrm{C}_{D^{-}}$Chaotic and unsuccessful scenario lacking strategy and pro-activity

This is one of the worst scenarios in that it combines two negative contrasting axes. On the one hand, a disarticulation of policies and an incoherence of strategies of action. And, on the other hand, because it exhibits a persistence of fragmentation and the isolated affirmation of municipalities.

Figure 10

\section{IMPLICATIONS AND ACTIONS OF THE $\mathrm{F}_{1} \mathrm{C}_{\mathrm{A}}$ FUTURE SCENARIO}

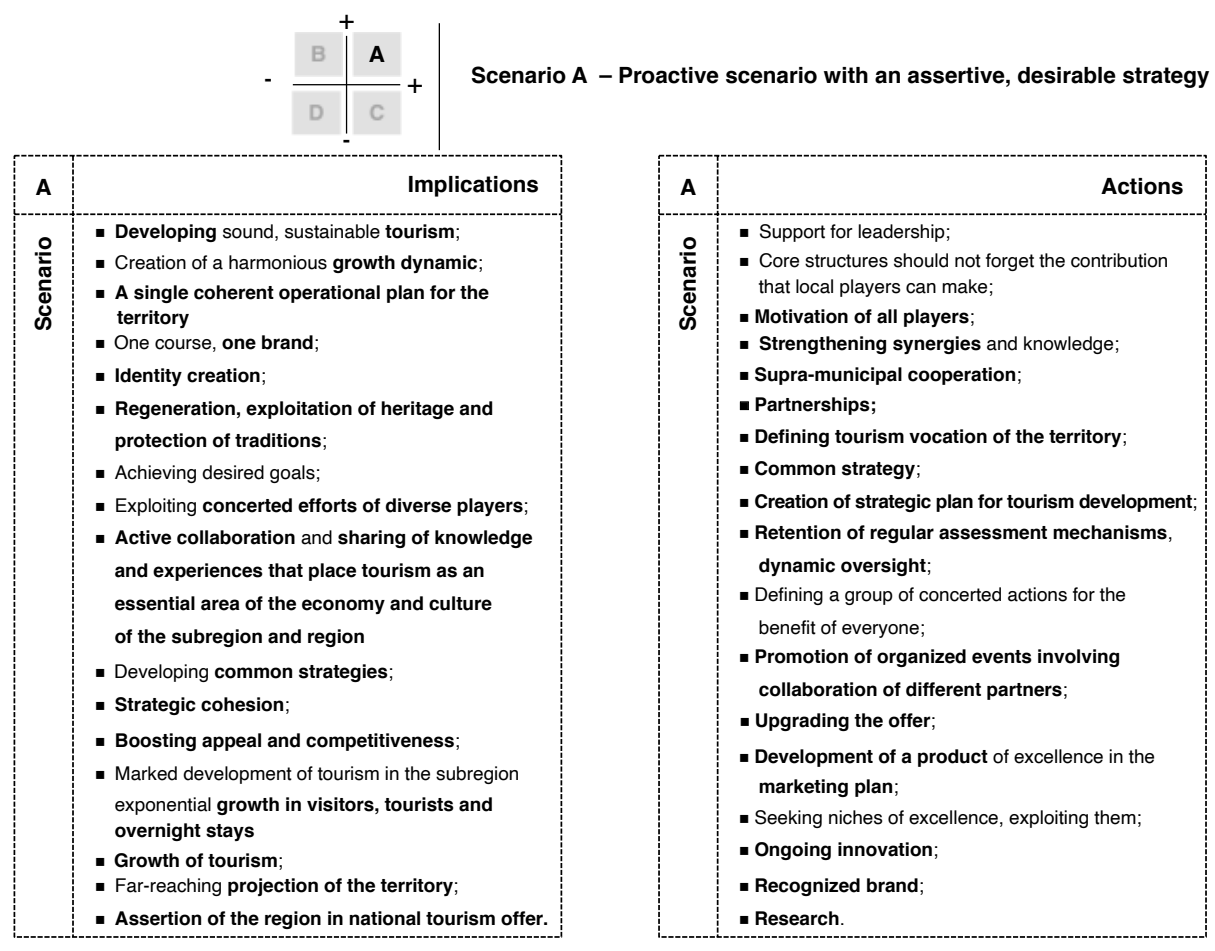

Source: Based on the opinion of the participants in the Delphi panel and questionnaire entitled: Tourism, heritage and local development in the Baixo Mondego. Strategic Management of the destination(s). 
Figure 11

IMPLICATIONS AND ACTIONS OF THE $\mathrm{F}_{2} \mathrm{C}_{\mathrm{B}}$ FUTURE SCENARIO

\begin{tabular}{|l|l|l|l|}
\hline - Scenario B - Proactive scenario lacking a coherent strategy, tourism without charisma \\
\hline - Stagnation of or poor tourism development; \\
\hline - Mussibility of success but with more effort by players
\end{tabular}

Source: Based on the opinion of the participants in the Delphi panel and questionnaire entitled: Tourism, heritage and local development in the Baixo Mondego. Strategic Management of the destination(s). 
Figure 12

IMPLICATIONS AND ACTIONS OF THE $\mathrm{F}_{3} \mathrm{C}_{\mathrm{C}}$ FUTURE SCENARIO

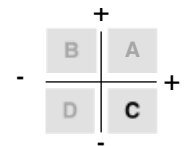

\begin{tabular}{|c|c|}
\hline C & Implications \\
\hline $\begin{array}{l}\text { 은 } \\
\text { 윯 } \\
\text { હ }\end{array}$ & $\begin{array}{l}\text { - Future assertion more difficult; } \\
\text { - Weak tourism development; } \\
\text { - The subregion will not have more or better tourism; } \\
\text { - Continuation of bad outcomes; } \\
\text { - Standardization of offer; } \\
\text { - Uniform dynamics; } \\
\text { - Paralysation of any rational activity in tourism; } \\
\text { - Possibility of entire strategy being blocked; } \\
\text { - Disconnection of tourism development policies; } \\
\text { - Little or even no territorial coherence; } \\
\text { - Instability and discontinuity; } \\
\text { - Slight increase in indicators for municipalities better } \\
\text { able to attract tourists; } \\
\text { - Piecemeal interventions of municipal nature, } \\
\text { incapable of assertion at national and } \\
\text { international level; } \\
\text { - Lack of intermunicipal cooperation will lead } \\
\text { to weakening of the outlined common strategy; } \\
\text { - Too many initiatives for the drafted goals, } \\
\text { poor quality of the initiatives, debasement } \\
\text { - No network organization. }\end{array}$ \\
\hline
\end{tabular}

Scenario C - Scenario with an inauspicious, fragmented strategy lacking self-confidence

Source: Based on the opinion of the participants in the Delphi panel and questionnaire entitled: Tourism, heritage and local development in the Baixo Mondego. Strategic Management of the destination(s). 
Figure 13

\section{IMPLICATIONS AND ACTIONS OF THE $\mathrm{F}_{4} \mathrm{C}_{\mathrm{D}}$ FUTURE SCENARIO}

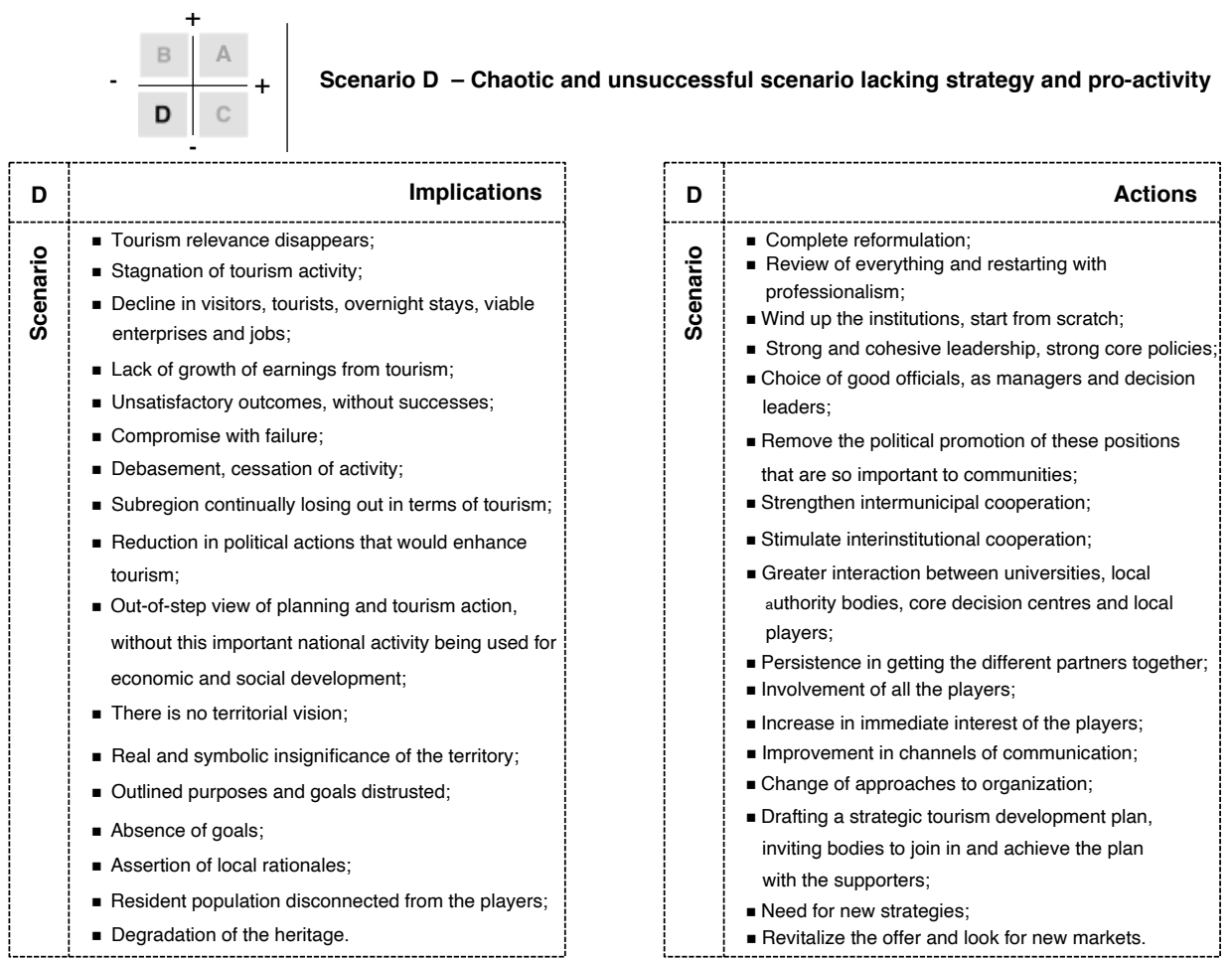

Source: Based on the opinion of the participants in the Delphi panel and questionnaire entitled: Tourism, heritage and local development in the Baixo Mondego. Strategic Management of the destination(s).

At the end of the defined 2020 period, in this monitoring stage it can be seen that the development of the destination has converged with some of the actions and implications that shape the $\mathrm{F}_{1} \mathrm{C}_{\mathrm{A}}$ scenario. The following figures illustrate the $2010-2020$ period initiatives in line with the provisions set out in the $\mathrm{F}_{1} \mathrm{C}_{\mathrm{A}}$ - Proactive scenario with an assertive, desirable strategy (in bold in Fig. $10 \mathrm{~F}_{1} \mathrm{C}_{\mathrm{A}}$ ). This was the one out of the four scenarios which mostly closely fit reality.

In line with the $\mathrm{F}_{1} \mathrm{C}_{\mathrm{A}}$ scenario, tourism is an essential activity in terms of socioeconomics. In fact, tourism in both the region and the subregion has been growing, following the trend noted in the Portugal destination (Moreira, 2018), although the length of stay remains low, less than two nights. There has been a considerable increase in the number of tourists (while the challenge of spreading visitors throughout the subregion and region as a whole persists) and a growing internationalization, that also results from the inclusion of the Asset, University of Coimbra - Alta and Sofia in the UNESCO World Heritage list, in 2013, as discussed in section 3.1. (Figures 3, 4 and 5). The application resulted from 
the joint effort of several stakeholders, namely the University of Coimbra and the Municipality of Coimbra, which boosted their synergies. The UNESCO listing motivated all of the tourism system players, as it increased the region's attractiveness and competitiveness. In 2017 the Portugal Centro Humanity Heritage Network (https://www.patrimoniomundialdocentro.pt/en/) was set up to bring together the four UNESCO World Heritage sites in the Centro of Portugal (the University of Coimbra - Alta and Sofia, the Alcobaça and Batalha Monasteries, and the Convent of Christin Tomar) to enhance and promote this tourist legacy with various initiatives geared towards tourism, cultural programming, education, and communication.

Meanwhile, a wide selection of events organized by different partners have contributed to raising awareness of the region (Fig. $10 \mathrm{~F}_{1} \mathrm{C}_{\mathrm{A}}$ ). The municipalities have sought to create national and international events, for example the RFM SOMNII electronic music festival, in Figueira da Foz, which first took place there in 2013. The Anozero - Coimbra Biennial of Contemporary Art, which started in 2015. The European Universities Games, European University Sports Association, 2018 event, in Coimbra. Among the sporting events, we find that Montemor-o-Velho has hosted several national, European and world events in the Centro de Alto Rendimento [High Performance Centre] on an increasingly regular basis since 2010. Recent events include the ICF Canoe Sprint World Championships in 2018. In terms of Meeting Industry, turning the San Francisco Convent into a Conference Centre in 2016, with various meeting areas plus a large auditorium for 1125 people, has helped to strengthen Coimbra's position in the International Congress and Convention Association (ICCA) ranking. It would be important to create a Conventions \& Visitors Bureau, which the Centro of Portugal does not have, to improve the positioning and competitiveness of the destination. The City of Coimbra is currently preparing its application to be the European Capital for Culture in 2027. Another amenity that has proved relevant is the PO.RO.S Museu Portugal Romano [PO.RO.S Roman Portugal Museum] in Sicó in Condeixa-a-Nova. It opened in May 2017 and has already been honoured with the Heritage in Motion 2018 prize. This is awarded by the European Museum Academy in partnership with Europa Nostra and is enabled by Europeana. PO.RO.S Museu Portugal Romano has also been singled out for the Best Achievement Award in the category Applications and interactive experiences.

There have been certain inter-municipal initiatives of some significance when it comes to exploiting the territory and tourism, such as: Coimbra's application to be a European Region of Gastronomy 2021, International Institute of Gastronomy, Culture, Arts and Tourism (IGCAT); The Carmelite Route (presented in 2011 and completed in 2019) stretches $111 \mathrm{~km}$ to the Sanctuary of Fátima and it now makes up part of the Caminhos de Fé (https://www.pathsoffaith.com); the Rede de Castelos e Muralhas do Mondego [Mondego Network of Castles and Walls], created in 2010 and the respective Agência para o Desenvolvimento dos Castelos e Muralhas Medievais do Mondego [Agency for the Development of the Mondego Castles and Medieval Walls], in 2011. This network has interactive audio guides in five languages (Portuguese, English, French, German and Spanish), which can be downloaded in the Android and iOS versions, and the application is available on the website. Free mobile applications have been created by local companies for visitors and tourists in this territory. These include the app Just in Time Tourist-JiTT. 
Travel, which creates technological solutions and specialized digital content for Tourism and Trips, setting up routes based on the location and time available. Efforts to rehabilitate, exploit and regenerate the heritage and safeguard traditions have emerged (Fig. $\left.10 \mathrm{~F}_{1} \mathrm{C}_{\mathrm{A}}\right)$, but these are still rather sporadic, and there is important development work to be done here, fundamentally in terms of Historic Centres. Equally important is the upgrading of the tourism offer. The initiatives are still very ad hoc, for example in terms of accommodation.

Changes in management and tourism have taken place between 2010 and 2020. In 2013 new regional tourism areas were created in mainland Portugal and the legal frameworks were set up to organize and operate of regional tourism authorities (Decree Law No. 33/2013) (ARPa, 2013a). Centro of Portugal came under the management of the Entidade Regional de Turismo Centro de Portugal [Regional Tourism Authority Centro of Portugal] (a Destination Management Organization DMO that oversees the largest and most diverse tourism region in Portugal consisting of a hundred municipalities, eight of which in the Baixo Mondego). In 2013 the Baixo Mondego saw its range extended from eight to nineteen municipalities (a change in line with the European Union's cohesion policy), joining with the Comunidade Intermunicipal Região de Coimbra [The Intermunicipal Community of the Coimbra Region] that was established by way of Law no. 75/2013 / 2013) (ARPb, 2013). The responsibilities of the Intermunicipal Community include promoting planning, strategic management, and the economic, social and environmental development of the territory, as mandated by the Estratégia Integrada de Desenvolvimento Territorial (20142020) [Integrated Territorial Development Strategy 2014-2020] (CIM RC, 2014). The Intermunicipal Community drew up the Intermunicipal Plan for Adaptation to Climate Change, a section of which was geared towards tourism (Moreira, Santos, Figueiredo \& Santos, 2017).

In December 2019 the Regional Tourism Authority Centro of Portugal presented their Plano Regional de Desenvolvimento Turístico 2020-2030 [Regional Tourism Development Plan 2020-2030] (ERTCP, 2019). This set up a common strategy (Fig. $10 \mathrm{~F}_{1} \mathrm{C}_{\mathrm{A}}$ ) and detailed the priority and secondary products for the Region of Coimbra. The goal is for each region to create Integrated Tourism Products with an Intermunicipal Base (defining tourism vocation of the territory). The Regional Tourism Development Plan 2020-2030 also includes a Marketing Plan. Centro of Portugal is a recognized brand today, following a rebranding initiative in 2015 designed to boost the regional unity and bring together the assets of the brand, to create an identity, and to increase awareness and lengthen tourists' visits. The destination was a finalist in the Destination Brand of The Decade competition, which recognises destinations that recorded appreciable growth in tourist numbers between 2010 and 2019, while gaining a reputation and developing new markets. A promotional campaign Turismo Centro Portugal - Visitar e Ficar é Ajudar [Tourism Centro of Portugal - To Visit and to Stay is to Help] was created after forest fires devastated the region in 2017 (Santos, Moreira, Figueiredo \& Silveira) and had a significantly negative impact on both tourism and the region's image. This campaign won the Gold Award at the International Travel \& Tourism Awards organized by the World Travel Market and the World Tourism Organization (WTO) in the category Best National Tourism Board/Destination Marketing Organization Campaign. The region's promotional videos have won several international awards. Centro de Portugal: Are You Ready? won nine awards and 
distinctions at eight international tourism film festivals, making it the 8th most awarded film of 2019. The region has been making its mark in the national tourism market and the eight municipalities of Baixo Mondego have contributed significantly. Many of these facts came about as the result of active collaboration, along with the sharing of knowledge and experiences between the different actors and interest groups, the development of common strategies is sometimes seen, although further development is needed, a harmonization of actions and strategic cohesion (Fig. $10 \mathrm{~F}_{1} \mathrm{C}_{\mathrm{A}}$ ). The Plano Regional de Desenvolvimento Turístico 2020-2030 [Regional Tourism Development Plan 2020-2030] stipulated the creation of a Tourism Observatory which was deemed essential to monitor assessment mechanisms so as to offer dynamic oversight. A predictive tourism system is to be set up as part of the Tourism Observatory. Scientific research plays a very important role here (Fig. $10 \mathrm{~F}_{1} \mathrm{C}_{\mathrm{A}}$ ). Therefore, a scenario like these is only shaped by creating mechanisms to link public entities, private agents, the scientific and technological system (universities, laboratories and research centres, whether public or private). The ongoing innovation that should be a crucial feature of the tourism products in this territory and the competitiveness that this entails means that this scenario greatly benefits from the transfer of knowledge.

\section{CONCLUSION}

The focus of this paper is on combining the Delphi technique and scenario creation as qualitative tourism forecasting techniques, not to report the results of the study that was conducted in lower Mondego River subregion, Centro of Portugal. So, the value of the research lies less in the results per se and more in the possibility of thinking futures, creating scenarios in tourism research and doing this by applying the Delphi technique.

A multi-technique research approach that combines the Delphi technique and scenario building can be useful to explore the futures and support destination management. Intelligent forecasts, those forecasts based on the formal and informal knowledge of tourism players and stakeholder-experts, and on their opinions (experts' judgments), can help tourist destination managers, planners, and decision makers to envision desirable futures and identify strategies, and to take decisions in a context of uncertainty and unpredictable futures.

In conclusion, it is relevant to explore the strengths and the limitations of this research approach based on tacit knowledge, the knowledge embedded in the accumulated experience acquired by tourism players and stakeholders, and indicate some guidelines that tourism researchers, and tourism analysts and tourism decision makers, should take into account in the future deployment of these techniques.

In terms of the strategic management of destinations at the local, subregional and regional levels, it is extremely important in a field such as tourism to take advantage of the subjective knowledge provided by organizations, institutions, businesses and associations (whose work is directly and indirectly linked to tourism) and to benefit from their experience.

In tourism at such local, subregional and regional scales of action, there is a certain fragmentation of institutions and interest groups, which is caused by: the multiplicity of stakeholders involved in the tourism system; the range of problems, needs and interests; 
spatial dispersion of stakeholders; the competitive nature of economic activities linked to tourism; the diversity of views on destination management; lack of forums for meeting, reflection and discussion; lack of consensus; and lack of a forward-looking strategic vision. Now, the dispersion of agents and interest groups compromises competitiveness and the claims of tourist destinations. The Delphi technique has the advantage of providing an opportunity for non-face-to-face discussion of an issue or a problem, from a forwardlooking perspective.

In the context of tourism and territory, development strategies must adopt a futures analysis that includes scenario-building exercises in order to strategically consider active measures and decision making. The findings suggest that the formal and informal knowledge that stakeholders and interest groups operating in the area of tourism at local, subregional and regional level can offer could greatly benefit the planning and management of tourist destinations. It is considered, however, that this relevance increases as the geographic scale increases; thus, from the local to the subregional and regional levels the involvement of stakeholders tends to increase, and strategic actions are defined within these geographic scales. The future of places, territories - ultimately of tourist destinations - is being built against a backdrop of a range of possibilities. It is on these scales that tourism happens. Getting the stakeholders to create scenarios, identifying implications and actions which define the narrative of the scenario, that is, implications and actions that give content and consistency to each future and whose combination makes it possible to describe the future based on the application of the technique Delphi, is possible, essentially when the Delphi technique involves 3 rounds, as demonstrated here.

This structured approach to the future that combines the Delphi technique and scenario building, that benefits from the knowledge and expertise of tourism stakeholders, could be used as an analytical tool to envision futures (probable future, inevitable future, possible future, desirable future), support multi-scale tourism destination management, inspire scientific circles tourism researchers, tourism analysts, and public or private sector tourism decision makers.

However, there is no tradition of foresight exercises or scenario creation at the multiscale levels, which compromises both the triggering of a foresight exercise and scenario building and an active participation in it. At these levels, the futures analysis faces some constraints: there are many different stakeholders and interest groups; policies and initiatives show some fragmentation and dispersion; it is more problematic to obtain detailed disaggregated information to give to participants and that supports a scenario-building exercise; it is harder to figure out how places in the larger geographical scales (local, subregional and regional) will be affected by the more global changes; it is harder to easily discern what are the driving forces of change and the critical uncertainties, aspects that influence futures analysis at these scales; to all of this is added the fact that tourism stakeholders focus their action very much on the short to medium term, so they very often exclude an analysis of the future(s). It is no accident that many of the foresight studies are carried out with reference to the scale of the national territory.

One of the study's limitations is the fact that the tourism stakeholders who participated in the panel are not used to thinking about the future(s) (or the futuribles), much less carrying out prospective analyses or participating in exercises of creating scenarios. A 
foresight culture presumes that organizations (companies and associations) recognize its relevance and appropriateness, so that in this context training is also crucial. In addition, a foresight culture implies that continuity and regularity are applied to foresight exercises, meaning that they become a more frequent practice. The creation of the European Tourism Futures Institute in 2009 identified this need precisely by seeking to meet it. It is important that in terms of managing tourist destinations, futures analysis, the Delphi technique or scenario building are used more often as a management practice and are strengthened in terms of research, with theoretical contributions and practical applications. In the Centro of Portugal Regional Tourism Development Plan 2020-2030 (ERTCP, 2019), the Tourism Observatory is tasked with creating a Tourism Predictive System capable of predicting tourism activity and anticipating trends / market behaviours, by way of calculation algorithms. The regional Destination Management Organization, Regional Tourism Authority Centro of Portugal, thus recognizes the importance of looking into the future(s). Therefore, it would be crucial if future research could enhance the formal and informal knowledge of regional tourism stakeholders, not only those from the eight municipalities of the Baixo Mondego but from all of the one hundred municipalities in the Centro Region, and carry out the same prospective analyses and scenario exercises, so as to guide them to envision their futures (the probable, inevitable, possible, and desirable ones).

\section{ACKNOWLEDGMENT}

This work was supported by the European Regional Development Funds, through the COMPETE 2020, Operational Programme Competitiveness and Internationalization under grant POCI-01-0145-FEDER-006891 and by national funds through the Portuguese Foundation for Science and Technology by (FCT) under the project FCT Ref: UID/GEO 04084/2013.

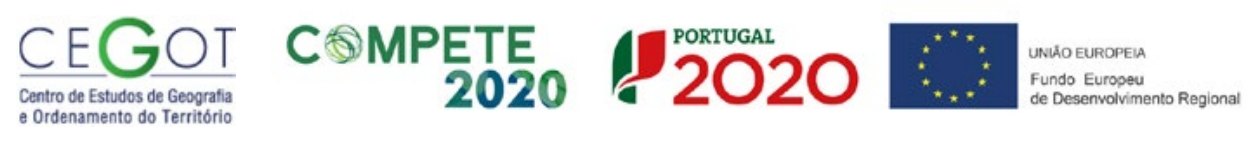

\section{REFERENCES}

AMER, M., DAIM, T.U. \&JETTER, A. (2013): «A review of scenario planning», Futures, vol. 46, pp. 23-40.

ASSEMBLEIA DA REPÚBLICA PORTUGUESA (ARP) (2013a): Lei n..$^{\circ}$ 33/2013 de 16

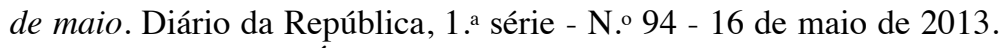

ASSEMBLEIA DA REPÚBLICA PORTUGUESA (ARP) (2013b): Lei n. ${ }^{\circ}$ 75/2013 de 12 de setembro. Diário da República, 1. ${ }^{a}$ série - N. ${ }^{\circ} 176$ - 12 de setembro de 2013.

BALLANTYNE, R., HUGHES, K. \& BOND, N. (2016): «Using a Delphi approach to identify managers' preferences for visitor interpretation at Canterbury Cathedral World Heritage Site», Tourism Management, vol. 46, pp. 72-80. 
BENCKENDORFF, P. (2007): «Envisioning sustainable tourism futures: An evaluation of the futures wheel method», Tourism and Hospitality Research, vol. 8 (1), pp. 25-36.

BERRY, T. (2006): «The predictive potential of the TALC model», in The tourism area life cycle. Vol. 2 Conceptual and theoretical issues. Clevedon, Channel View, pp. 254-279.

BOTTERILL, D. \& PLATENKAMP, V. (2012): «Delphi method», in Key concepts in tourism research. London, Sage, pp. 56-59.

BRIEDENHANN, J. (2009): «Socio-cultural criteria for the evaluation of rural tourism projects - a Delphi consultation», Current Issues in Tourism, vol. 12 (4), pp. 379-396.

BRIEDENHANN, J. \& BUTTS, S. (2006): «Application of the Delphi technique to rural tourism project evaluation», Current Issues in Tourism, vol. 9 (2), pp. 171-190.

BUTLER, R. (1980): «The concept of a tourist area cycle of evolution: implications for management resources»,Canadian Geographer, vol. 24 (1), pp. 5-12.

BUTLER, R.W. (2006): «The concept of a Tourist Area Cycle of evolution: Implications for management of resources», in R. W. Butler (Ed.), The Tourism Area Life Cycle. Vol. 1, Applications and modifications. Clevedon, Channel View, pp. 3-12.

CALANTONE, R.J., DI BENEDETTO, C.A.\& BOJANIC, D. (1987): «A comprehensive review of the tourism forecasting literature», Journal of Travel Research, vol. 26 (2), pp. 28-39.

CHARLTON, J.R.H. (2001): «Delphi technique», in The SAGEencyclopedia of social science research methods, vol. 1.London, SAGE, pp. 244-245.

CHEN, L., NG, E., HUANG, S.-C. \& FANG, W.-T. (2017): «A self-evaluation system of quality planning for tourist attractions in Taiwan: An integrated AHP-Delphi Approach from career professionals», Sustainability, vol. 9, 1751, pp. 2-18.

COMUNIDADE INTERMUNICIPAL REGIÃO DE COIMBRA (CIMRC) (2014): Estratégia Integrada de Desenvolvimento Territorial da Região de Coimbra (20142020). Coimbra, Sociedade de Consultores Augusto Mateus \& Associados.

COOKE, R.M. (1991): Experts in uncertainty. New York, Oxford University Press.

COOPER, C. (2008): «An introduction to tourism», in Tourism: Principles and practice, $4^{\text {th }}$ Ed. Harlow, Pearson Education, pp. 2-25.

CUNLIFFE, S. (2002): «Forecasting risks in the tourism industry using the Delphi technique», Tourism, vol. 50 (1), pp. 31-41.

DACONTO, G. \& SHERPA, L.N. (2010): «Applying scenario planning to park and tourism management in Sagarmatha National Park, Khumbu, Nepal», Mountain Research and Development, vol. 30 (2), pp. 103-112.

DAYÉ, C. (2016): «'A fiction of long standing': Techniques of prospection and the role of positivism in US Cold War social science, 1950-65», History of the Human Sciences, vol. 29 (4-5), pp. 35-58.

DELBECQ, A.L., VAN DE VEN, A.H. \& GUSTAFSON, D.H. (1986): Group techniques for program planning: A guide to nominal group and Delphi processes. Middleton, Green Briar Press.

DONOHOE, H.M. \& NEEDHAM, R.D. (2009): «Moving best practice forward: Delphi charac- teristics, advantages, potential problems, and solutions», International Journal of Tourism Research, vol. 11 (5), pp. 415-437. 
EDGELL, D.L., SEELY, R.L. \& IGLARSH, H.J. (1980): «Forecasts of international tourism to the USA», International Journal of Tourism Management, vol. 1 (2), pp. 109-113.

ENTIDADE REGIONAL TURISMO CENTRO DE PORTUGAL (ERTCP) (2019): Plano Regional de Desenvolvimento Turístico 2020-2030. Lisboa, Deloitte.

FEFER, J.P., STONE, S. D.-U., DAIGLE, J. \& SILKA, L. (2016): «Using the Delphi technique to identify key elements for effective and sustainable visitor use planning frameworks», SAGE Open, vol. 6 (2), pp. 1-16.

FERNANDES, G.P. (2015):«Prospective methodologies to support tourism destinations management», in Innovation, management and education in tourism and hospitality: Applied research. Guarda, Instituto Politécnico da Guarda, pp. 31-37.

FRECHTLING, D.C. (1996): Practical tourism forecasting. Oxford, Butterworth-Heinemann.

FRECHTLING, D.C. (2001): Forecasting tourism demand: Methods and strategies. Oxford, Butterworth-Heinemann.

GANI, A.A. (2015): «Factors encouraging public participation in planning for tourism in protected area: A modified Delphi study», in Developments of the New Tourism Paradigm in the Asia Pacific Region, $21^{\text {st }}$ Asia Pacific Tourism Association Annual Conference, Malaysia, Kuala Lumpur, May 14-17, pp. 4-8.

GARCÍA-MELÓN, M., GÓMEZ-NAVARRO, T. \& ACUÑA-DUTRA, S. (2012): «A combined ANP-Delphi approach to evaluate sustainable tourism», Environmental Impact Assessment Review, vol. 34, pp. 41-50.

GARROD, B. \& FYALL, A. (2005): «Revisiting Delphi: The Delphi technique in tourism research», in Tourism research methods: Integrating theory with practice. Oxfordshire, Cabi, pp. 85-98.

GIDLEY, J.M. (2013): «Global knowledge futures: Articulating the emergence of a new meta-level field», Integral Review, vol. 9 (2), pp. 145-172.

GODET, M. (1993): Manual de prospectiva estratégica: Da antecipação à acção. Lisboa, Publicações Dom Quixote.

GODET, M. (1996): «Les fondements de la prospective. Le mariage de l'intuition et de la raison»,Cahier EspacesProspective et Tourisme, vol.49, pp. 107-111.

GONÇALVES, A.R. (2003): A componente cultural do turismo urbano como oferta complementar ao produto "sol e praia". Lisboa, Gabinete de Estudos e Prospectiva Económica e Instituto de Financiamento e Apoio ao Turismo.

GONÇALVES, A.R. (2006): «The Delphi technique applied to urban and cultural tourism research in the Algarve», Encontros Científicos, n 2, pp. 110-118.

GÖSSLING, S. \& SCOTT, D. (2012): «Scenario planning for sustainable tourism: An introduction»,Journal of Sustainable Tourism, vol. 20 (6), pp. 773-778.

GOUIRAND, P. (1996): «À quoi sert la prospective?», Cahier Espaces Prospective et Tourisme, vol. 49, pp. 112-115.

GREEN, H., HUNTER, C. \& MOORE, B. (1989): «Assessing the environmental impact of tourism development: The use of the Delphi technique», International Journal of Environmental studies, vol. 35 (1), pp. 51-62. 
GREEN, H., HUNTER, C. \& MOORE, B. (1990): «Application of the Delphi technique in tourism», Annals of Tourism Research, vol. 17 (2), pp. 270-279.

GUNN, C.A. \& VAR, T. (2002): Tourism planning: Basics, concepts, cases (2 ${ }^{\text {nd }}$ ed.). London, Routledge.

GUPTA, U.G. \& CLARKE, R.E. (1996): «Theory and applications of the Delphi technique: A bibliography (1975-1994)», Technological Forecasting and Social Change, vol. 53 (2), pp. 185-211.

GUTTENTAG, D.A. \& SMITH S.L.J. (2016): «Delphi technique», in Encyclopedia of tourism. Cham, Springer, pp. 231-232.

JENNINGS, G. (2010): Tourism research. Milton, John Wiley \& Sons.

KAHN, H. \& WIENER, A.J. (1967): The year 2000: A framework for speculation on the next thirty-three years. New York, The Macmillan.

KARDARAS, D.K., KARAKOSTAS, B. \& MAMAKOU, X.J. (2013):«Content presentation personalisation and media adaptation in tourism web sites using Fuzzy Delphi Method and Fuzzy Cognitive Maps», Expert Systems with Applications, vol. 40 (6), pp. 2.331-2.342.

KAUFMANN, P.R. (2016): «Integrating factor analysis and the Delphi method in scenario development: A case study of Dalmatia, Croatia», Applied Geography, vol. 71, pp. 56-68.

KAYNAK, E., BLOOM, J. \& LEIBOLD, M. (1994): «Using the Delphi technique to predict future tourism potential», Marketing Intelligence \& Planning, vol. 12 (7), pp. 18-29.

KAYNAK, E. \& CAVLEK, N. (2007): «Measurement of tourism market potential of Croatia by use of Delphi qualitative research technique», Journal of East-West Business, vol. 12 (4), pp. 105-123.

KAYNAK, E. \& MACAULEY, J.A. (1984): «The Delphi technique in the measurement of tourism market potential: The case of Nova Scotia», Tourism Management, vol. 5 (2), pp. 87-101.

KAYNAK, E. \& MARANDU, E.E. (2006): «Tourism market potential analysis in Botswana: A Delphi study», Journal of Travel Research, vol.45 (2), pp. 227-237.

KAYNAK, E. \& ROJAS-MÉNDEZ, J.I. (2014): «Predicting tourism market potential of Chile by use of a qualitative forecasting technique», International Journal of Commerce and Management, vol. 24 (2), pp. 167-179.

KONU, H. (2015): «Developing nature-based tourism products with customers by utilising the Delphi method», Tourism Management Perspectives, vol. 14, pp. 42-54.

KUO, N.-W., HSIAO, T.-Y. \& YU, Y.-H. (2005): «A Delphi-matrix approach to SEA and its application within the tourism sector in Taiwan», Environmental Impact Assessment Review, vol. 25 (3), pp. 259-280.

LANDETA, J. (2006): «Current validity of the Delphi method in social sciences»,Technological Forecasting \& Social Change, vol. 73, pp. 467-482.

LANDETA, J., MATEY, J., RUÍZ, V. \& VILLARREAL, O. (2002): «Alimentación de modelos cuantitativos con información subjectiva: aplicación Delphi en la elaboración de un modelo de imputación del gasto turístico individual en Catalunya, Qüestiió, vol. 26 (1-2), pp. 175-196. 
LEE, C.-F. \& KING, B.E. (2008): «Using the Delphi method to assess the potential of Taiwan's hot springs tourism sector»,International Journal of Tourism Research, n'10(4), pp. 341-352.

LEE, C.-F. \& KING, B.E. (2009): «A determination of destination competitiveness for Taiwan's hot springs tourism sector using the Delphi technique», Journal of Vacation Marketing, vol. 15 (3), pp. 243-257.

LENNON, J.J. \& YEOMAN, I. (2007): «Drivers and scenarios of Scottish tourism - shaping the future to 2015», Tourism Recreation Research, vol. 32 (1), pp. 69-82.

LINSTONE, H.A. \& TUROFF, M. (Eds.) (2002): The Delphi method: Techniques and applications. New Jersey, Department of Information Systems, New Jersey's Science \& Technology University. Retrieved fromhttp://is.njit.edu/pubs/delphibook/

LIN, V.S. \& SONG H. (2015a): «Judgmental forecasting in tourism», in Contemporary tourism reviews, vol. 1.Oxford, Goodfellow Publishers, pp. 300-343.

LIN, V.S.\& SONG H. (2015b): «A review of Delphi forecasting research in tourism», Current Issues in Tourism, vol.18 (12), pp. 1.099-1.131.

LIU, J.C. (1988): «Hawaii tourism to the year 2000: A Delphi forecast», Tourism Management, vol.9 (4), pp. 279-290.

LOCKE, M. (2015):«Stakeholders' interests, power, and influence in the development of the Auckland MICE sector», in Developments of the New Tourism Paradigm in the Asia Pacific Region, $21^{\text {st }}$ Asia Pacific Tourism Association Annual Conference, Malaysia, Kuala Lumpur, May 14-17, pp. 228-231.

MAI, T. \& SMITH, C. (2018):«Scenario-based planning for tourism development using system dynamic modelling: A case study of Cat Ba Island, Vietnam», Tourism Management, vol. 68, pp. 336-354.

MARQUES, J. (2013): Turismo de Negócios. Convention \& Visitors Bureau na Região Centro de Portugal. Unpublished doctoral thesis, Universidade de Coimbra, Portugal. Retrieved fromhttp://hdl.handle.net/10316/24285

MARQUES, J. \& SANTOS, N. (2016): «Developing business tourism beyond major urban centres: The perspectives of local stakeholders», Tourism and Hospitality Management, vol. 22 (1), pp. 1-15.

MASBERG, B., CHASE, D. \& MADLEM, M. (2004): «A Delphi study of tourism training and education needs in Washington State», Journal of Human Resources in Hospitality \& Tourism, vol.2 (2), pp. 1-22.

MCLENNAN, C-L, PHAM, T. D., RUHANEN, L., RITCHIE, B. W., MOYLE, B. (2012): «Counter-factual scenario planning for long-range sustainable local-level tourism transformation», Journal of Sustainable Tourism, vol. 20 (6), pp. 801-822.

MILLER, G. (2001): «The development of indicators for sustainable tourism: Results of a Delphi survey of tourism researchers», Tourism Management, n²2(4), pp. 351-362.

MOELLER, G.H. \& SHAFER, E.L. (1983): The use and misuse of Delphi forecasting, in Recreation and planning management. London, E. \& F. N. Spon, pp. 96-104.

MOELLER, G.H. \& SHAFER, E.L. (1994): «The Delphi technique: A tool for long-range travel and tourism planning», in Travel, tourism, and hospitality research. A handbook for managers and researchers. Nova Iorque, Jonh Wiley \& Sons, pp. 473-480. 
MOREIRA, C.O. (2012): «A técnica Delphi aplicada à investigação em Turismo», in Patrimónios, territórios e turismo cultural: Recursos, estratégias e práticas, Coleção Iberografias, vol. 19.

Guarda, Centro de Estudos Ibéricos, Âncora Editora, pp. 419-440.Retrieved fromhttp:// hdl.handle.net/10316/46623

MOREIRA, C.O. (2013):Turismo, território e desenvolvimento: Competitividade e gestão estratégica de destinos. Unpublished doctoral thesis, Universidade de Coimbra, Portugal. Retrieved fromhttp://hdl.handle.net/10316/24446

MOREIRA, C.O. (2018): «Portugal as a tourism destination: Paths and trends». Méditerranée, $\mathrm{n}^{\mathrm{o}}$ 130. https://journals.openedition.org/mediterranee/10402

MOREIRA, C., SANTOS, N., FIGUEIREDO, R. \& SANTOS, T. (2017): «Turismo», in Plano Intermunicipal de Adaptação às Alterações Climáticas - Comunidade Intermunicipal Região de Coimbra. Coimbra, Comunidade Intermunicipal da Região de Coimbra, pp. 805-895. Retrieved fromhttps://www.cim-regiaodecoimbra.pt/wp-content/uploads/2018/10/PIAAC-CIM-RC-versão-web.pdf

MÜLLER, H. (1998): «Long-haul tourism 2005: Delphi study», Journal of Vacation Marketing, n4(2), pp. 193-201.

NORTHCOTE, J., LEE, D., CHOK, S. \& WEGNER, A. (2008): «An email-based Delphi approach to tourism program evaluation: Involving stakeholders in research design», Current Issues in Tourism, vol. 11 (3), pp. 269-279.

NYAUPANE, G. \& BUZINDE, C. (2017): «Scenario planning: A planning tool for an uncertain future. Tourism Travel and Research Association: Advancing Tourism Research Globally. 1 Retrieved August 7, 2018. University of Massachusetts Amherst. Retrieved fromhttp://scholarworks.umass.edu/ttra/2017/Qual_Research_Papers/1

O'CONNOR, P. \& FREW, A. (2000): «Evaluating electronic channels of distribution in the hotel sector: A Delphi study»,Information Technology and Tourism, vol. 3 (3/4), pp. 177-193.

OH, M., KIM, S. \& LEE, A. (2013): «Development of an evaluation scale for inter-country tourism industry competitiveness using the Delphi technique and analytic hierarchy process», International Journal of Tourism Sciences, vol.13 (2), pp. 1-32.

PAGE, S.J., YEOMAN, I, CONNELL, J. \& GREENWOOD,C.(2010): «Scenario planning as a tool to understand uncertainty in tourism: The example of transport and tourism in Scotland in 2025», Current Issues in Tourism, vol. 13 (2), pp. 99-137.

PAN, S. Q., VEGA, M., VELLA, A.J., ARCHER, B.H. \& PARLETT, G.R. (1995): «A mini-Delphi approach: An improvement on single round techniques», Progress in Tourism and Hospitality Research, vol. 2, pp. 27-39.

PEREZ, A.S. (Dir.) (2001): Apuntes de metodología de la investigación en turismo. Madrid, Organización Mundial del Turismo.

PILLKAHN, U. (2008): Using trends and scenarios as tools for strategy development. Erlangen, Publicis Corporate Publishing.

PIZZITUTTIA, F., WALSHC, S.J., RINDFUSSD, R.R., GUNTERA, R., QUIROGAA, D., TIPPETTE, R. \& MENAA, C.F. (2017): «Scenario planning for tourism management: A participatory and system dynamics model applied to the Galapagos Islands of Ecuador», Journal of Sustainable Tourism, vol. 25 (8), pp. 1.117-1.137. 
POSTMA, A. (2015): «Investigating scenario planning - a European tourism perspective», Journal of Tourism Futures, vol. 1 (1), pp. 46-52.

PRIDEAUX, B., LAWS, E. \& FAULKNER, B. (2003): «Events in Indonesia: Exploring the limits to formal tourism trends forecasting methods in complex crisis situations», Tourism Management, vol. 24 (4), pp. 475-487.

RAMOS, A.R.C. DE C.V. (2001): «Termalismo/turismo termal - contextos, impactes e potencialidades», in Investigação em turismo, livro de atas, ciclo de debates 2001 Lisboa, Instituto de Financiamento e Apoio ao Turismo, pp. 295-309.

RAMOS, A.R.C. DE C.V. (2005): O termalismo em Portugal. Dos factores de obstrução à revitalização pela dimensão turística. Unpublished doctoral thesis, Universidade de Aveiro, Portugal. Retrieved fromhttp://biblioteca.sinbad.ua.pt/Teses/2007000223

ROBINSON, A.E. (1979): «Tourism and the next decade: A look to the future through 'A Return to Delphi'», in Proceedings of Travel and Tourism Research Association Tenth Annual Conference. Travel and Tourism Research Association, Salt Lake City, Utah, pp. 269-282.

SANTOS, N., MOREIRA, C.O., FIGUEIREDO, R. \& SILVEIRA, L. (2018): «Impactos dos incêndios florestais na atividade turística. Vulnerabilidade e resiliência nos territórios afetados pelos fogos de 2017 na Região Centro», in Turismo no Centro de Portugal: Potencialidades e tendências. Lisboa, Atual, pp. 105-135.

SEELY, R.L., IGLARSH, H. \& EDGELL, D. (1980): «Utilising the Delphi technique at international conferences: A method for forecasting international tourism conditions», Travel Research Journal, nº, pp. 30-35.

SILVA, J.A., JAFARI, J. \& SCOTT, N. (Eds.) (2010): «Introduction», in Tourism development and management. Challenges and opportunities for Algarve, Portugal. Faro, Universidade do Algarve, pp. 19-26.

SILVEIRA, L. (2016): O turismo de iates: Estratégia de desenvolvimento para a Figueira da Foz. Unpublished doctoral thesis, Universidade de Coimbra, Portugal. Retrieved fromhttp://hdl.handle.net/10316/31172

SMITH, S. (2013): Tourism analysis: A handbook $2^{\text {nd }}$ edition. Oxon, Routledge.

SOLNET, D.J., BAUM, T., KRALJ, A., ROBINSON, R.N.S., RITCHIE, B.W. \& OLSEN, M. (2014): «The Asia-Pacific tourism workforce of the future: Using Delphi techniques to identify possible scenarios», Journal of Travel Research, vol. 53 (6), pp. 693-704.

SPENCELEY, A. (2008): «Requirements for sustainable nature-based tourism in transfrontier conservation areas: A Southern African Delphi consultation», Tourism Geographies, vol.10 (3), pp. 285-311.

SZPILKO, D. (2014): «The use of Delphi method in the process of building a tourism development strategy in the region», Economics and Management, vol. 4, pp. 329-346.

TAYLOR, R.E. \& JUDD, L.L. (1989): «Delphi method applied to tourism», in Tourism marketing and management handbook. New York, Prentice Hall, pp. 95-98.

UYSAL, M. \& CROMPTON, J.L. (1985): «An overview of approaches used to forecast tourism demand», Journal of Travel Research, vol. 23 (4), pp. 7-15.

VAN DOORN, J. (1982): «Can futures research contribute to tourism policy?»,Tourism Management, vol. 3 (3), pp. 149-166. 
VAN DOORN, J. (1986): «Scenario writing: A method for long-term tourism forecasting?»,Tourism Management, vol.7 (1), pp. 33-49.

VAN GINNEKEN, R. (2011): «Expert attitudes to management contracts in the Dutch hotel industry: a Delphi approach», Journal of Hospitality and Tourism Management, vol. 18(1), pp. 140-146.

VAR, T. (1984): «Delphi and GSV techniques in tourism forecasting and policy design», Problems of Tourism, vol. 3, pp. 41-52.

VEAL, A.J. (2018): Research methods for leisure and tourism: A practical guide (5 $5^{\text {th }}$ ed.). Harlow, Prentice Hall.

VON BERGNER, N.M. \& LOHMANN, M. (2014): «Future challenges for global tourism: A Delphi survey», Journal of Travel Research, vol. 53 (4), pp. 420-432.

WALL, G. (2009): «Tourism and development: Towards sustainable outcomes», in Cultural tourism and sustainable local development. Aldershot, Ashgate, pp. 31-46.

WESTON, R. \& DAVIES, N. (2007): «The future of transport and tourism: A Delphi approach», Tourism and Hospitality Planning \& Development, vol. 4 (2), pp. 121-133.

WITT, S.F., MOUTINHO, L., HUARNG, K.-H. \& YU, C.A. (2018): Demand modeling and fuzzi time series forecasting, in Strategic management in tourism $3^{\text {rd }}$ edition. Oxfordshire, Cabi, pp. 45-72.

WITT, S.F. \& WITT, C.A. (1995): «Forecasting tourism demand: A review of empirical research», International Journal of Forecasting, vol. 11 (3), pp. 447-475.

WRIGHT, G., CAIRNS, G.M. \& BRADFIELD, R. (2013): «Scenario methodology: New developments in theory and practice: Introduction to the Special Issue», Technological Forecasting and Social Change, vol. 80 (4), pp. 561-565.

WU, K., YU, G. \& ZENG, T. (2011): «Establishment of teaching quality indexes system in tourism management undergraduate education by Delphi analysis», $2^{\text {nd International }}$ Conference on Emergency Management and Management Sciences (ICEMMS), Beijing, China (2011.08.8-2011.08.10) pp. 301-304. Retrieved fromhttps://ieeexplore.ieee. org/stamp/stamp.jsp?tp=\&arnumber $=6015681$

YEOMAN, I. (2008): Tomorrow's tourist. London, Routledge.

YEOMAN, I. \& LEDERER, P. (2005): «Scottish tourism: Scenarios and vision» „Journal of Vacation Marketing, vol. 11 (1), pp. 71-87.

YONG, Y.W., KENG, K.A. \& LENG, T.L. (1989): «A Delphi forecast for the Singapore tourism industry: Future scenario and marketing implications», International Marketing Review, vol. 6 (3), pp. 35-46.

ZHANG, J. (2017): «Evaluating regional low-carbon tourism strategies using the fuzzy Delphi-analytic network process approach», Journal of Cleaner Production, vol. 141, pp. 409-419. 
